\title{
PENENTUAN DAERAH PROSPEK MINERALISASI \\ MENGGUNAKAN METODE GEOKIMIA TANAH, DAERAH NANGA BANGIK, KECAMATAN BOYAN TANJUNG, KABUPATEN KAPUAS HULU, PROVINSI KALIMANTAN BARAT
}

\author{
DETERMINATION OF MINERALIZATION PROSPECTS \\ BY SOIL GEOCHEMISTRY METHOD IN NANGA BANGIK AREA, \\ BOYAN TANJUNG DISTRICT, KAPUAS HULU REGENCY, \\ WEST KALIMANTAN PROVINCE
}

Sulaeman, Ernowo, dan Denni Widhiyatna

Pusat Sumber Daya Mineral Batubara dan Panas Bumi

sulaeman.1988@esdm.go.id

\begin{abstract}
ABSTRAK
Sebagai negara tropis pelapukan tanah di Indonesia berlangsung intensif. Penentuan daerah prospek mineralisasi pada penyelidikan ini menggunakan metode geokimia tanah, dengan melakukan pengambilan sampel dari tanah lapukan tersebut. Daerah Nanga Bangik, Desa Jemah, Kecamatan Boyan Tanjung, Kabupaten Kapuas Hulu, Provinsi Kalimantan Barat memiliki kondisi geologi yang sangat memungkinkan terbentuk mineralisasi logam. Penyelidikan ini dilakukan untuk menentukan daerah prospek mineralisasi.
\end{abstract}

Sebanyak 135 sampel tanah telah diambil menggunakan sistem ridge and spurs dari horizon B dengan jarak antar titik lokasi sampel $75-100$ meter. Sampel tanah tersebut dianalisis di Laboratorium Pusat Sumber Daya Mineral Batubara dan Panas Bumi (PSDMBP). Analisis laboratorium menggunakan metode AAS (Atomic Absorption Spectroscopy), unsur yang dianalisis meliputi $\mathrm{Cu}, \mathrm{Pb}, \mathrm{Zn}, \mathrm{Fe}, \mathrm{Mn}, \mathrm{Ag}$ dan $\mathrm{Au}$. Metode analisis statistik yang dilakukan meliputi analisis distribusi, perhitungan nilai threshold dengan metode perhitungan Mean+2 $S D E V$ dan Median+2 MAD dan korelasi antar unsur dengan Faktor Analisis.

Berdasarkan perhitungan nilai threshold menggunakan dua metode statistik yang berbeda, didapatkan beberapa nilai anomali dan tiga faktor kelompok unsur: Faktor 1: Pb-Fe-Zn-Ag Faktor 2: Mn-Cu dan Faktor 3 berupa unsur Au yang diinterpretasikan berhubungan dengan adanya mineralisasi logam. Didapatkan tiga daerah prospek mineralisasi logam di Bukit Empajak, Bukit Pirang dan Bukit Limau.

Kata kunci: pelapukan, tanah, geokimia eksplorasi, threshold, anomali

\section{ABSTRACT}

The tropical climate of Indonesia causes rock weathering. Soil from weathered rocks can be analyzed to determine the anomalies element to define the mineralization prospect areas using the geochemical methods. This study was carried out in the Nanga Bangik area with geological conditions favorable for mineralization.

A total of 135 soil samples were collected from horizon $B$ along ridge and spurs with sample intervals 75 - 100 meters. All samples were analyzed at the laboratory of the Center for Mineral Coal and Geothermal Resources in Bandung. Geochemical analysis was conducted using the Atomic Absorption Spectroscopy method, for the elements of $\mathrm{Cu}, \mathrm{Pb}, \mathrm{Zn}, \mathrm{Fe}, \mathrm{Mn}, \mathrm{Ag}$, and $\mathrm{Au}$. Statistical distribution analysis, threshold calculation using mean+2SDEV and Median+2MAD and correlation between Factor Analysis were combined to determine the anomalies areas. 


\section{MAKALAH ILMIAH}

Based on the calculation of the threshold using two different statistical methods, several anomalous values and groups of three factors were obtained: Factor 1: Pb-Fe-Zn-Ag Factor 2: $\mathrm{Mn}-\mathrm{Cu}$ and Factor 3 in the form of element Au which was interpreted by the presence of metal mineralization. Three mineralization prospect areas were found in Bukit Empajak, Bukit Pirang and Bukit Limau.

Keywords: weathering, soil, geochemical exploration, threshold, anomaly

\section{PENDAHULUAN}

Tanah dan material lapukan yang terdapat di atas cebakan bijih dapat digunakan dalam studi geokimia eksplorasi untuk menemukan cebakan bijih yang baru (Grunsky, 2010). Analisis geokimia tanah pada kegiatan eksplorasi merujuk pada anomali unsur dan pola sebaran unsur pathfinder yang dihubungkan dengan tipe deposit (Bradshaw dan Lett, 1980). Analisis statistik dilakukan pada data geokimia tanah sebagai alat untuk interpretasi adanya potensi mineralisasi pada suatu area (Closs \& Nichol, 1975; Garret, drr, 1980).

Secara administratif daerah penyelidikan termasuk daerah Nanga Bangik, Desa
Jemah, Kecamatan Boyan Tanjung, Kabupaten Kapuas Hulu, Provinsi Kalimantan Barat (Gambar 1). Daerah ini dipilih karena secara regional memiliki potensi keterdapatan endapan mineral logam. Hal ini ditunjukkan dengan adanya beberapa kegiatan eksplorasi oleh perusahaan-perusahaan pemegang IUP eksplorasi komoditi emas dan antimon.

Maksud penyelidikan ini untuk mendapatkan sampel tanah dilanjutkan dengan analisis kimia dan pengolahan statistik untuk mendapatkan gambaran sebaran dan korelasi antar unsur. Tujuan penyelidikan ini yaitu untuk mendapatkan daerah prospek mineralisasi yang dapat dijadikan target penyelidikan selanjutnya.

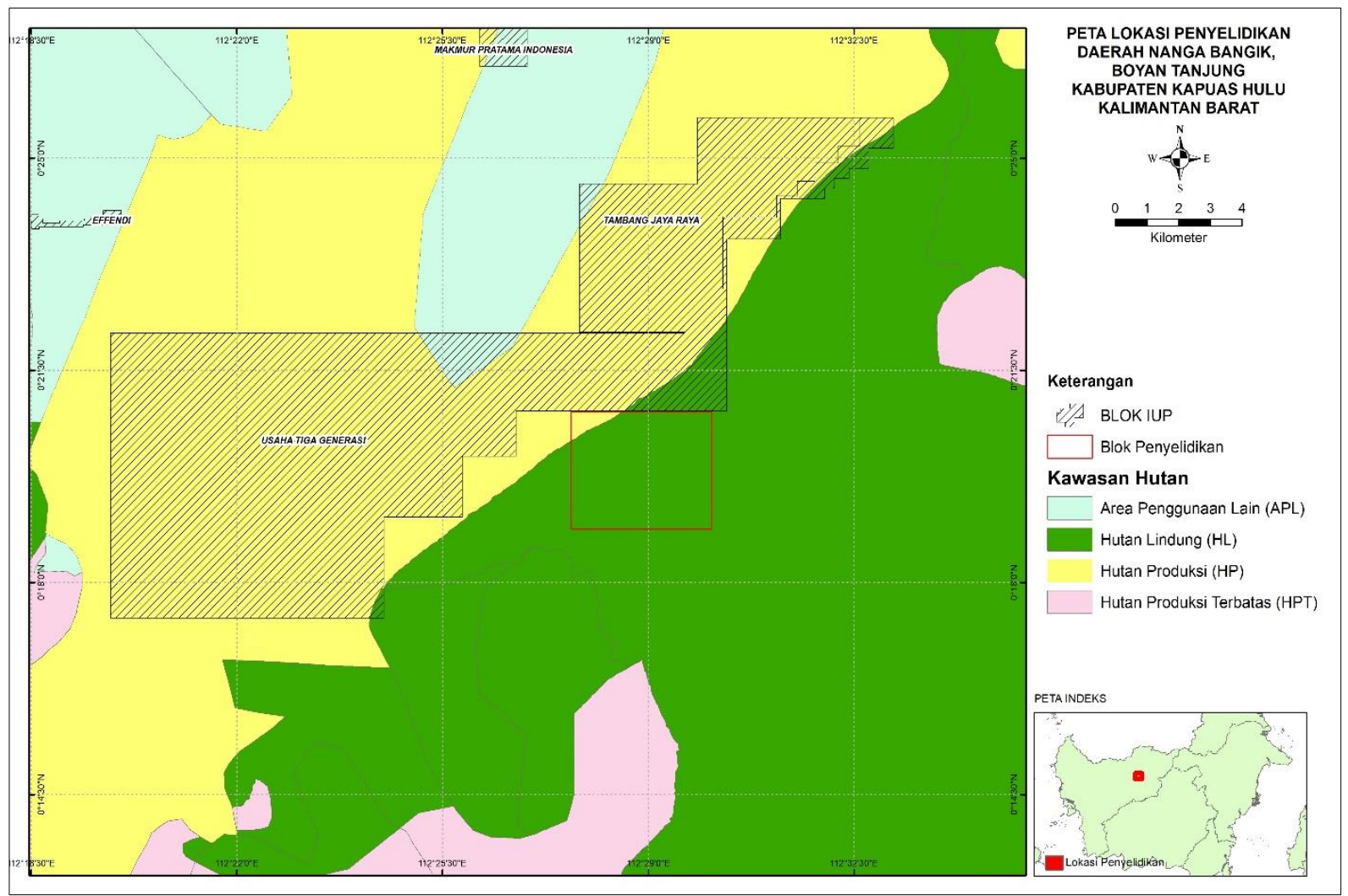

Gambar 1. Lokasi penyelidikan daerah Nanga Bangik 


\section{METODOLOGI}

\section{Pemetaan Geologi dan Pengambilan Sampel}

Pemetaan geologi dilakukan dengan pengamatan dan pengukuran aspek-aspek geologi. Sampel tanah diambil dari horizon $B$ pada punggungan dan puncak bukit dengan interval $50-100$ meter. Kedalaman sampel tanah yang diambil sekitar 70 - 100 cm (Rose, drr., 1979).

\section{Analisis Laboratorium}

Sebanyak 135 sampel tanah dipreparasi dan dianalisis kandungan unsurnya menggunakan metode atomic absorption spectrophotometry (AAS). Unsur-unsur yang dianalisis terdiri dari $\mathrm{Cu}, \mathrm{Pb}, \mathrm{Zn}, \mathrm{Fe}$, $\mathrm{Mn}$, Ag dan Au. Analisis dilakukan di Laboratorium Kimia Pusat Sumber Daya Mineral Batubara dan Panas Bumi (PSDMBP).

\section{Analisis Statistik}

Hasil dari analisis kandungan unsur $\mathrm{Cu}$, $\mathrm{Pb}, \mathrm{Zn}, \mathrm{Fe}, \mathrm{Mn}, \mathrm{Ag}$ dan $\mathrm{Au}$ dilakukan pengolahan dan analisis statistik secara univariat dan multivariat. Kumpulan data geokimia akan lebih mudah apabila menggunakan analisis statistik (Laurent, drr, 2010). Analisis distribusi tertuang dalam bentuk histogram untuk data geokimia setiap unsur dengan menggunakan aplikasi SPSS (Statistical Package for Social Sciences). Histogram tersebut dilakukan pada asli data geokimia dan juga pada data geokimia yang telah ditranformasi ke dalam bentuk log (logtransformed). Selain itu, distribusi setiap unsur dilakukan ke dalam bentuk scatterplot ataupun diagram Harker untuk mengetahui korelasi positif atau negatif dari setiap unsur (Carranza, 2008).

Kedua data baik asli ataupun data geokimia log-transformed setiap unsurnya dihitung nilai rata-rata (mean) dan standar deviasi. Penghitungan nilai ambang batas (threshold) dilakukan dengan metode perhitungan sebagai berikut: [mean + 2 SDEV]

Dalam geokimia eksplorasi, nilai dari (mean \pm 2 standard deviation) pada awalnya digunakan untuk identifikasi sekitar 2,5\% nilai batas upper (or lower) dari nilai ekstrim dan perhitungan lebih lanjutnya digunakan sebagai nilai threshold pada kumpulan data (Hawkes dan Webb, 1962). Pada metode perhitungan nilai threshold ini kumpulan data geokimia haruslah mempunyai distribusi yang normal. Untuk itu, pada data geokimia yang mempunyai nilai ekstrim (outlier) harus dihilangkan terlebih dahulu dalam penentuan nilai threshold atau metode lainnya adalah dengan menggunakan logtransformed terlebih dahulu.

\section{[Median + 2 MAD]}

Metode perhitungan nilai threshold dengan $[$ Median +2 median absolute deviation (MAD)], merupakan pendekatan yang kuat yang mudah dipahami dan banyak digunakan dalam menghitung nilai threshold (Reimann drr., 2005).

\section{Analisis korelasi antar unsur}

Pada umumnya metode hubungan antar unsur (multivariate) yang sering digunakan dalam mempelajari dan kuantifikasi hubungan antar unsur dalam data geokimia eksplorasi terdiri dari Principal Components Analysis (PCA), Factor Analysis (FA), Cluster Analysis (CA), Regression Analysis (RA) dan Discriminant Analysis (DA). PCA dan FA digunakan dalam mempelajari hubungan antar unsur dalam kumpulan dari banyak unsur. Dalam artikel ini PCA atau FA digunakan untuk mengetahui hubungan antar unsur, beberapa diantaranya dapat menggambarkan adanya keterjadian mineralisasi (Carranza, 2008).

Ketika dihasilkan kumpulan data geokimia yang besar, factor analysis dapat digunakan untuk mengurangi jumlah variabel yang diteliti dan menggambarkan variabilitas diantara variabel yang berkorelasi (Reimann, drr., 2002). Di dalam 


\section{MAKALAH ILMIAH}

factor analysis (FA), Principal Factor Analysis (PFA) dan Metode Maximum Likelihood (ML) merupakan dua metode yang dapat melakukan ekstraksi faktor umum. Secara prinsip, PFA seperti halnya Principal Components Analysis (PCA). Ketika menggunakan factor analysis, factor rotation yang harus digunakan Varimax (Kaiser, 1958), Promax (Hendrickson dan White, 1964), Oblimin (Harman, 1976) atau Quartimin (Carrol, 1953).

\section{GEOLOGI}

Geologi daerah Kabupaten Kapuas Hulu disusun oleh satuan-satuan stratigrafi batuan dasar granitik-gabro, Kompleks Busang, Kelompok Selangkai, Batuan Gunungapi Piyabung, Kelompok Mandai, Batuan Terobosan Sintang dan Aluvium (Pieters, drr., 1993) (Gambar 2). Satuan stratigrafi tertua terdiri atas batuan dasar granitik-gabro dan Kompleks Busang dimana keduanya diperkirakan berumur Perm-Trias. Kompleks Busang dibedakan dengan batuan dasar karena keanekaragaman susunan batuan pembentuknya yang terdiri dari granit, granodiorit, diorit dan gabro termalihkan; sekis, gneiss, kuarsit, serpentinit dan harzburgit, di atasnya diendapkan secara tidak selaras Kelompok Selangkai berumur Kapur Bawah-Atas, terdiri dari batuanbatuan sedimen yang terdiri atas batugamping, batupasir, konglomerat dan batulanau. Pada Zaman Tersier diendapkan secara tidak selaras Batuan Gunungapi Piyabung yang terdiri dari tufa dan aglomerat yang bersusunan asam sampai menengah berumur Eosen dan pada Eosen Atas diendapkan batupasir dan batulumpur yang termasuk ke dalam satuan stratigrafi Kelompok Mandai.

Terobosan Sintang merupakan batuan intrusi yang terdiri dari diorit, diorit porfir, andesit dan dasit porfir yang diperkirakan merupakan bagian dari kegiatan magmatisme/vulkanisme pada Miosen Bawah. Satuan ini menerobos batuanbatuan dari Kelompok Selangkai, Batuan Gunungapi Piyabung dan Kelompok Mandai.

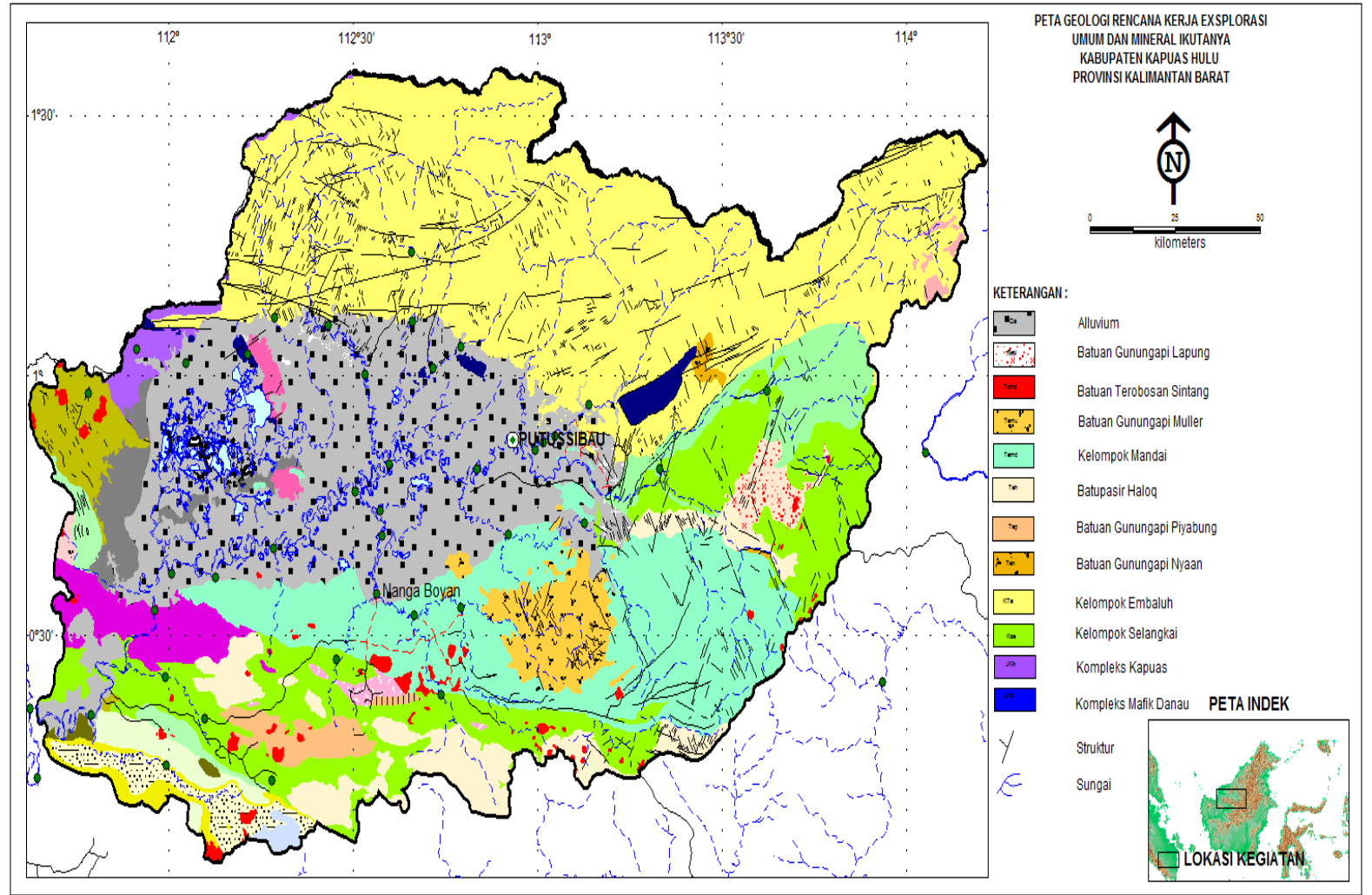

Gambar 2. Geologi regional Kabupaten Kapuas Hulu (modifikasi dari Pieters dkk., 1993) 
Daerah Boyan Tanjung tersusun oleh litologi Satuan Batupasir Grewake merupakan batuan dasar yang berada di daerah penyelidikan. Pada beberapa bagian mengandung mineral magnetit secara tersebar. Struktur perlapisan batuan masih nampak jelas dengan arah umum jurus dan kemiringan $\mathrm{N} 330^{\circ} \mathrm{E} / 40^{\circ}$. Satuan Batulempung-Serpih diendapkan selaras di atas Satuan Batupasir Grewake. Satuan Batupasir Arkose diendapkan secara selaras di atas Satuan BatulempungSerpih. Ketiga satuan batuan tersebut diperkirakan merupakan bagian dari Kelompok Selangkai yang berumur Kapur. Satuan Tufa-Tufa Breksi merupakan satuan batuan yang paling muda umurnya yang menutupi secara tidak selaras terhadap tiga satuan batuan di bawahnya. Satuan batuan ini diperkirakan merupakan bagian dari batuan Gunung Api Piyabung berumur Eosen. Keempat satuan batuan tersebut di atas diterobos oleh retas mikrodiorit dan andesit yang diperkirakan bagian dari Intrusi Sintang berumur Miosen Bawah sebagaimana yang dijumpai di Sungai Emplui. Adanya terobosan ini menyebabkan terjadinya ubahan silisifikasi dan mineralisasi tipe urat polimetalik dengan mineralisasi pirit, kalkopirit dan sphalerit (Kisman, drr., 2015).

Kisman, drr (2015) melakukan kegiatan penyelidikan dan mendelineasi anomali $\mathrm{Au}$ dari sampel sedimen sungai aktif. Kadar tertinggi sampel sedimen sungai aktif mencapai $821 \mathrm{ppb}$ Au dari Sungai Jolik di Desa Jemah, Kecamatan Boyan Tanjung, Kabupaten Kapuas Hulu. Dari hasil analisis mineragrafi terhadap sampel batuan termineralisasi sulfida dengan tipe impregnation yang terdapat di Sungai Bangik menunjukkan mineral logam yang teridentifikasi adalah pirit dan hydrous iron oxide dengan kandungan $20 \mathrm{ppm} \mathrm{Cu}, 31$ ppm Pb, 56 ppm Zn, 1675 ppm Mn dan 17 ppb Au.

\section{HASIL PENYELIDIKAN}

\section{Geologi Daerah Penyelidikan}

Daerah penyelidikan tersusun oleh empat satuan batuan yang berurut dari tua ke muda, yaitu Satuan Batupasir Grewake, Satuan Batulempung-Serpih, Satuan TufaTufa Breksi dan Satuan Batuan Intrusi (Gambar 3). Satuan Batupasir Grewake merupakan batuan dasar yang berada di daerah penyelidikan dengan komposisi mineral terdiri atas mineral mafik, sedikit feldspar dan kuarsa. Satuan BatulempungSerpih diendapkan secara selaras di atas Satuan Batupasir Grewake. Umumnya dicirikan oleh batulempung dan serpih dengan arah perlapisan $\mathrm{N} 320^{\circ} \mathrm{E} / 40^{\circ}$. Di beberapa lokasi batulempung tufaan mengalami pengekaran kuat dan limonitisasi dimana pada bidang kekarnya terisi oleh oksida besi. Satuan Batuan Intrusi umumnya berupa andesit, pada beberapa lokasi dijumpai batuan mikrodiorit yang sudah termineralkan sulfida pirit dan terdapat rekahan-rekahan yang terisi oleh mineral silika yang mengalami oksidasi (Gambar 4). Retas ini diperkirakan merupakan bagian dari intrusi Sintang yang berumur Miosen Bawah.

\section{Sampel Tanah}

Sebanyak 135 sampel tanah yang telah diambil dari daerah penyelidikan dengan distribusi titik sampel dalam Gambar 5. Sampel dianalisis dengan metode AAS untuk unsur-unsur antara lain $\mathrm{Cu}, \mathrm{Pb}, \mathrm{Zn}$, $\mathrm{Fe}, \mathrm{Mn}, \mathrm{Ag}$ dan Au. Dari hasil analisis laboratorium tersebut diperoleh besaran kadar dari setiap unsur yang dianalisisnya dan didapat kumpulan data geokimia.

\section{PEMBAHASAN}

Perhitungan descriptive statistic dari unsur-unsur hasil analisis laboratorium disajikan pada Tabel 1. Skewness dari masing-masing unsur yang relatif positif mengindikasikan distribusi yang tidak normal. Kumpulan data geokimia unsur selalu menunjukan lebih dari satu populasi yang merepresentasikan suatu proses tertentu. Proses geologi secara spasial bergantung antara satu dengan yang lainnya dan selalu menjelaskan suatu bagian dari kadar yang tertinggi dari masing-masing unsur pada sampel geokimia. Sehingga pada umumnya kumpulan data geokimia tidak mengikuti 


\section{MAKALAH ILMIAH}

model distribusi normal (Vistelius, 1960; Reimann dan Filzmoser, 1999). Uji normalitas dilakukan untuk mengubah dari distribusi data yang tidak normal (Miesch, 1977; Joseph dan Bhaumik, 1997). Uji normalitas mentransformasikan data menjadi model distribusi normal untuk unsur $\mathrm{Cu}, \mathrm{Pb}$ dan $\mathrm{Zn}$ (Gambar 6) dan (Gambar 7), sementara itu untuk unsur $\mathrm{Au}$, Ag (Gambar 8) mendekati distribusi normal.

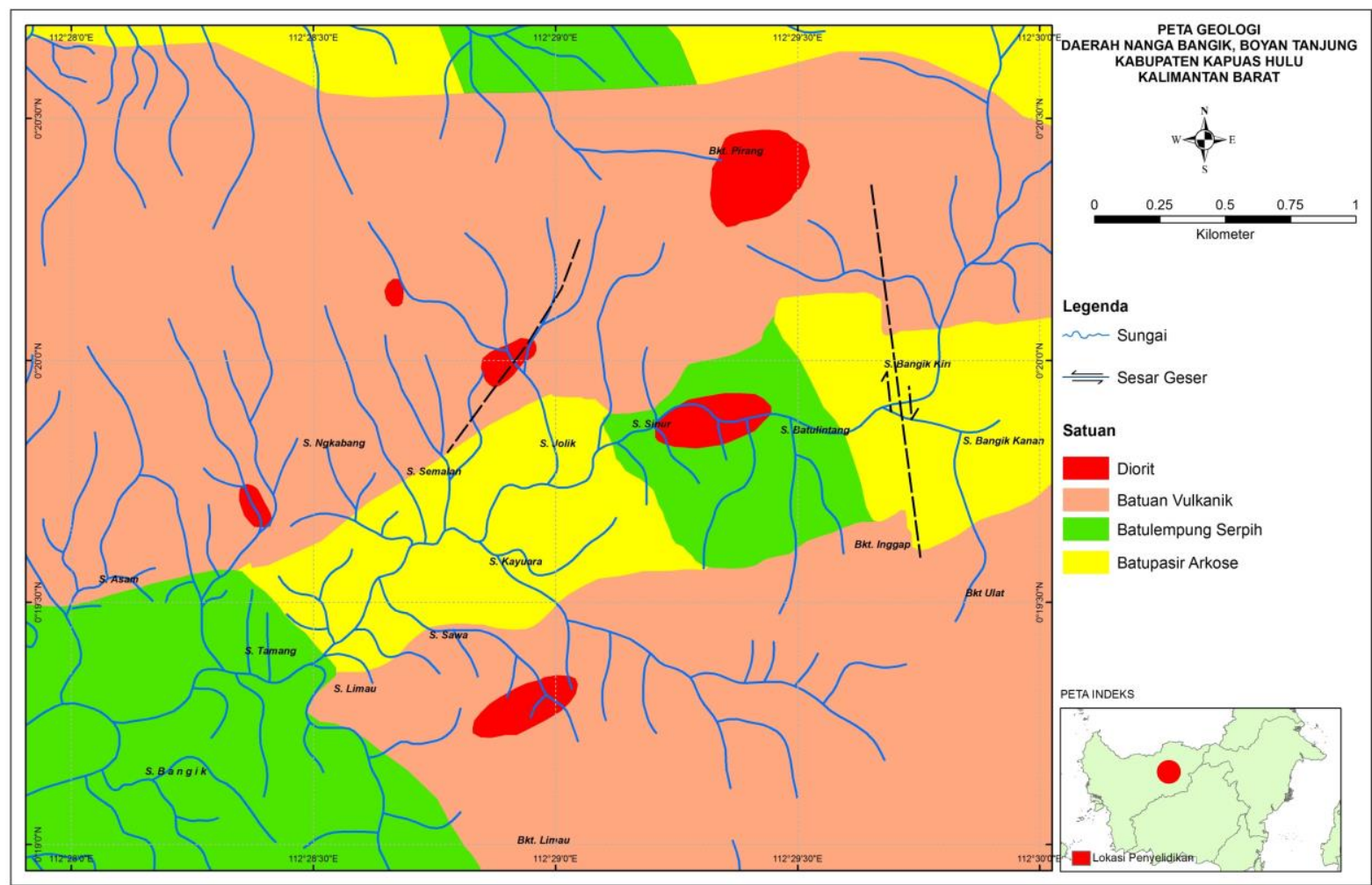

Gambar 3. Peta geologi daerah penyelidikan

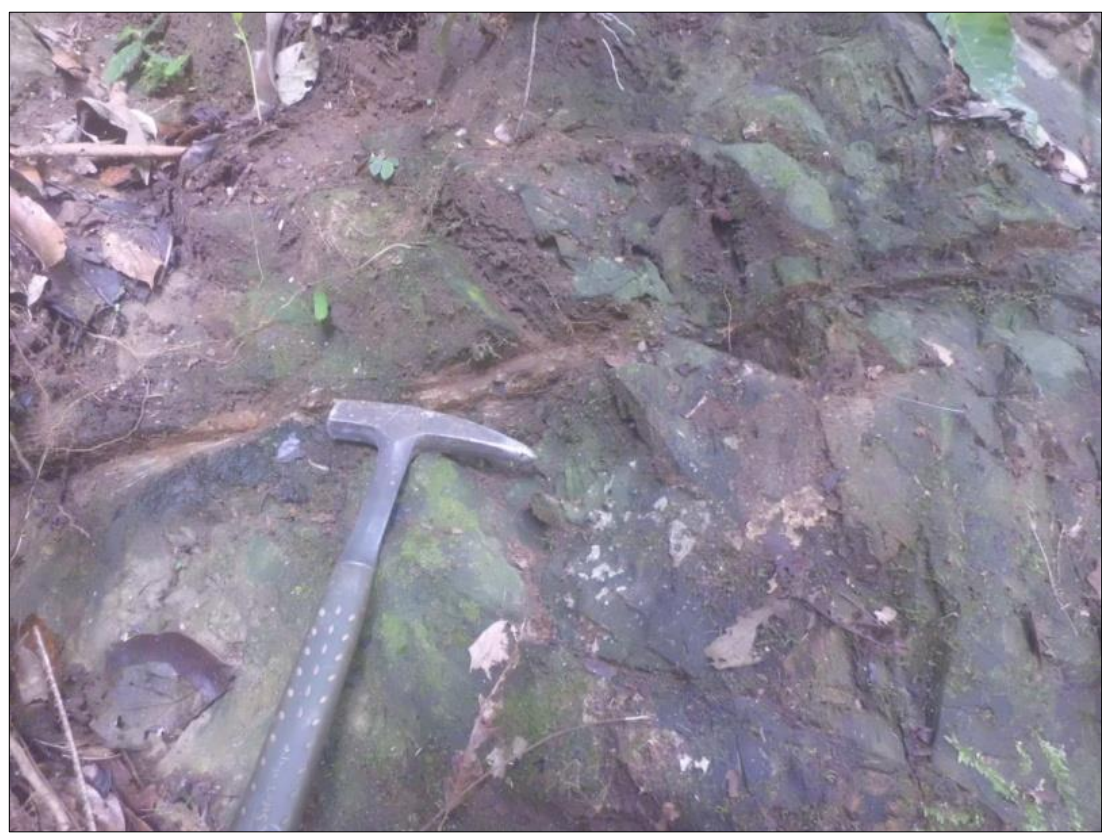

Gambar 4. Urat kuarsa dengan lebar 2,0 cm mengisi rekahan pada tubuh batuan intrusi di lereng Bukit Pirang 


\section{MAKALAH ILMIAH}

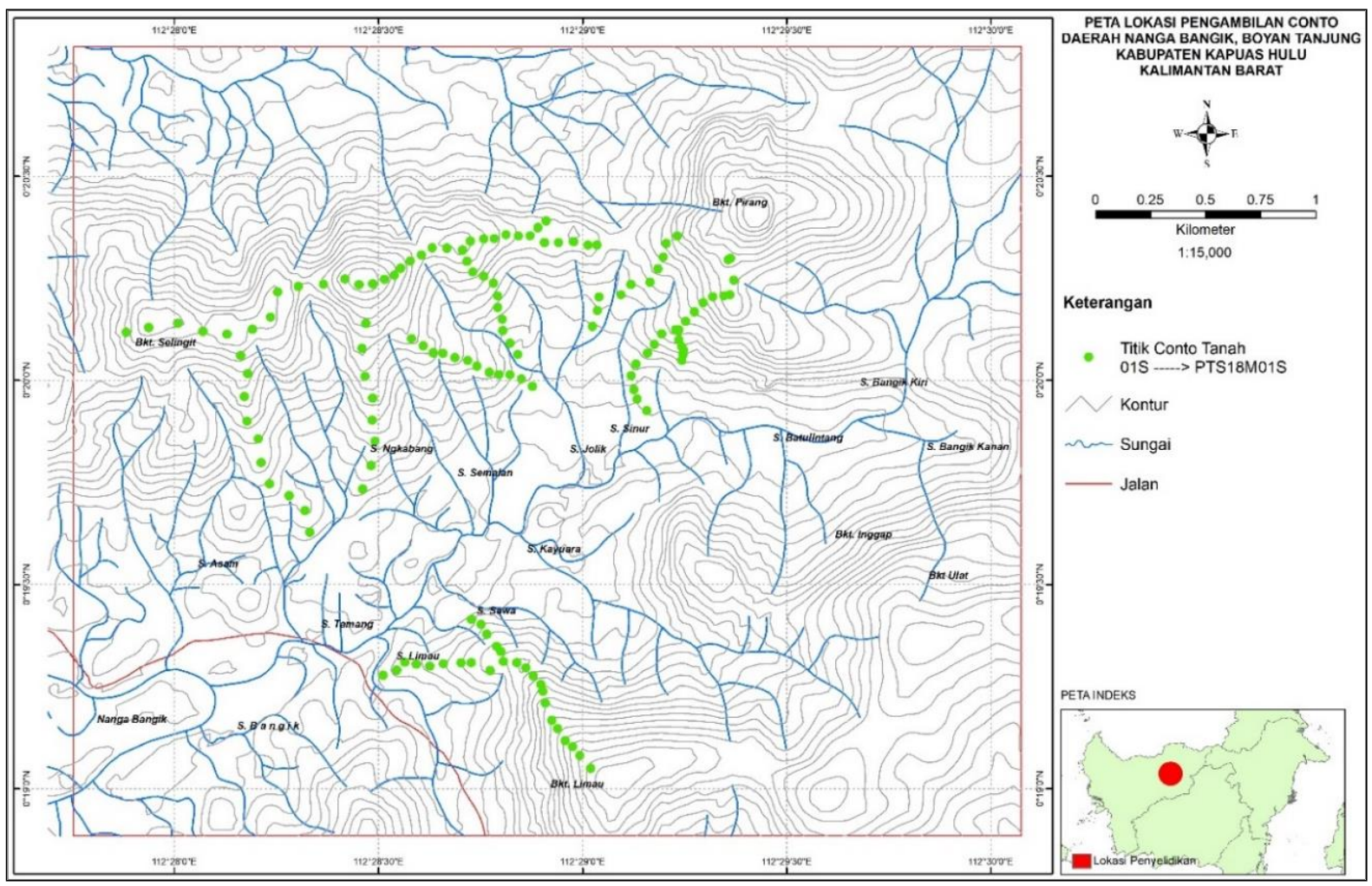

Gambar 5. Peta lokasi sampel tanah daerah Nanga Bangik

Tabel 1. Rangkuman descriptive statistic dari data geokimia soil/tanah daerah Nanga Bangik

\begin{tabular}{lrrrrrrr} 
& $\mathrm{Cu}$ & $\mathrm{Pb}$ & $\mathrm{Zn}$ & $\mathrm{Mn}$ & $\mathrm{Fe}$ & $\mathrm{Ag}$ & $\mathrm{Au}$ \\
\hline Mean & 15,87 & 30,62 & 70,25 & 155,13 & 2,98 & 1,43 & 9,61 \\
Standard Error & 1,27 & 0,80 & 4,27 & 11,47 & 0,10 & 0,08 & 1,04 \\
Median & 11 & 29 & 57 & 119 & 2.86 & 1.2 & 6 \\
Mode & 5 & 31 & 46 & 100 & 3.43 & 0.9 & 4 \\
Standard Deviation & 14,72 & 9,29 & 49,58 & 133,31 & 1,22 & 0,95 & 11,87 \\
Sample Variance & 216,53 & 86,37 & $2.457,76$ & $17.772,77$ & 1,48 & 0,89 & 140,98 \\
Kurtosis & 7,06 & 5,04 & 12,77 & 11,42 & 0,90 & 7,32 & 41,27 \\
Skewness & 2,25 & 1,64 & 3,14 & 3,02 & 0,79 & 2,37 & 5,63 \\
Range & 85 & 61 & 355,8 & 821 & 6,77 & 6 & 108 \\
Minimum & 1 & 13 & 1,2 & 30 & 0,96 & 0,3 & 1 \\
Maximum & 86 & 74 & 357 & 851 & 7,73 & 6,3 & 109 \\
Sum & 2.142 & 4.134 & $9.484,2$ & 20.942 & 402,09 & 193,6 & 1.187 \\
Count & 135 & 135 & 135 & 135 & 135 & 135 & 131 \\
\hline
\end{tabular}

Catatan: Satuan kadar Fe dalam \%, Au dalam ppb dan unsur lainnya dalam ppm 


\section{MAKALAH ILMIAH}
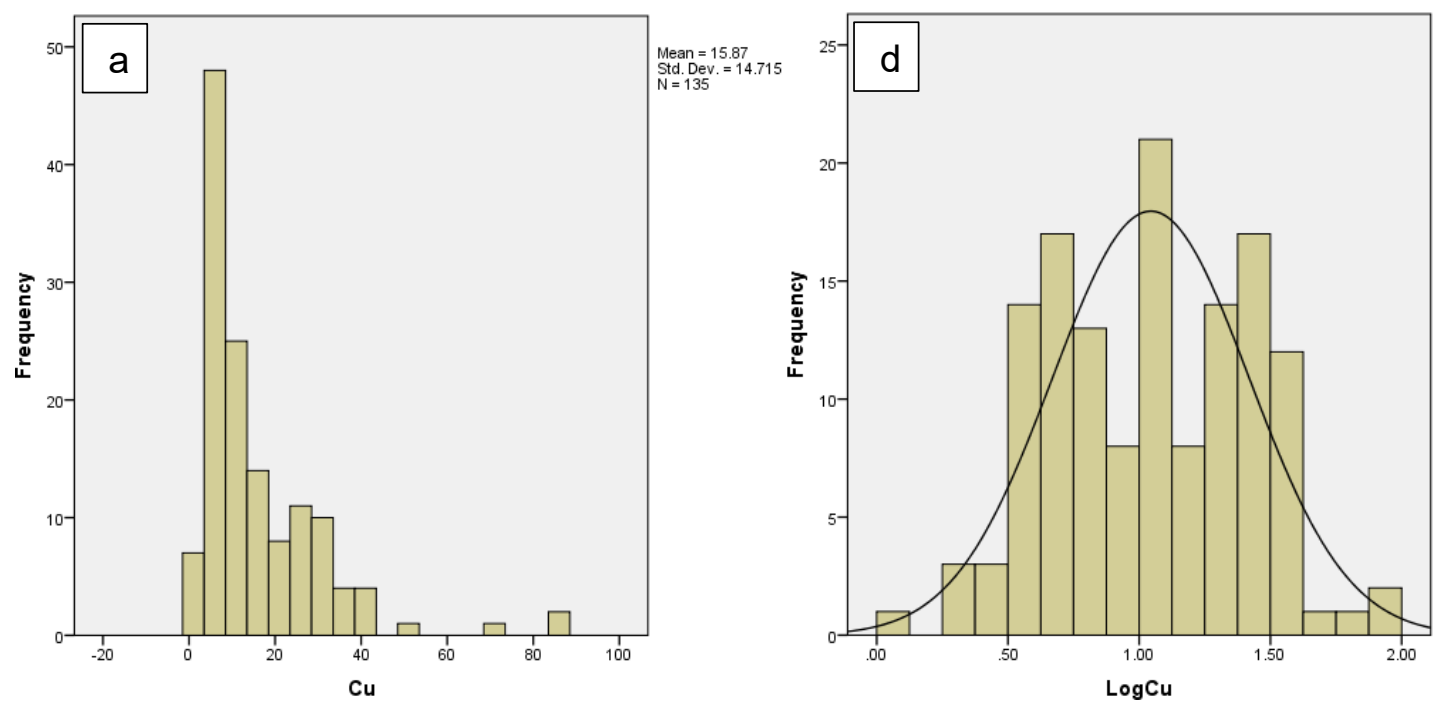

Mean 1.04 .045
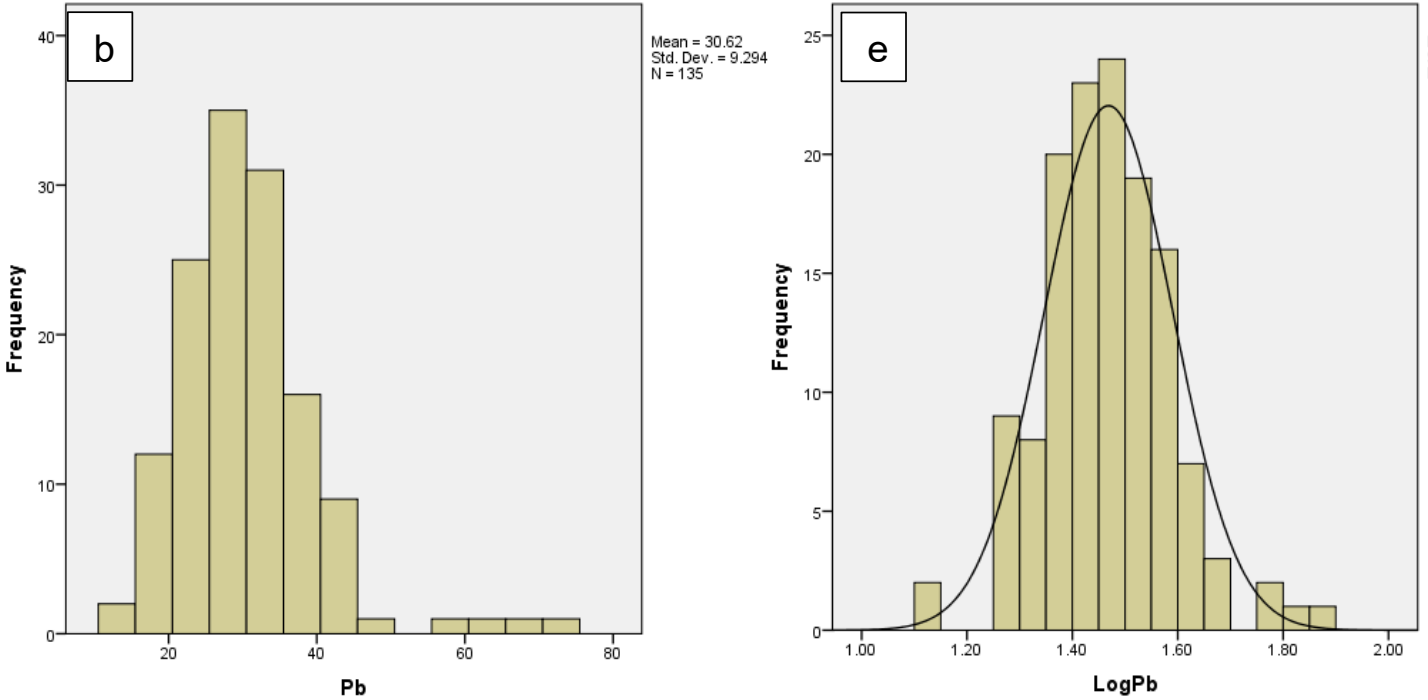

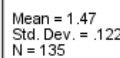

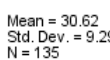
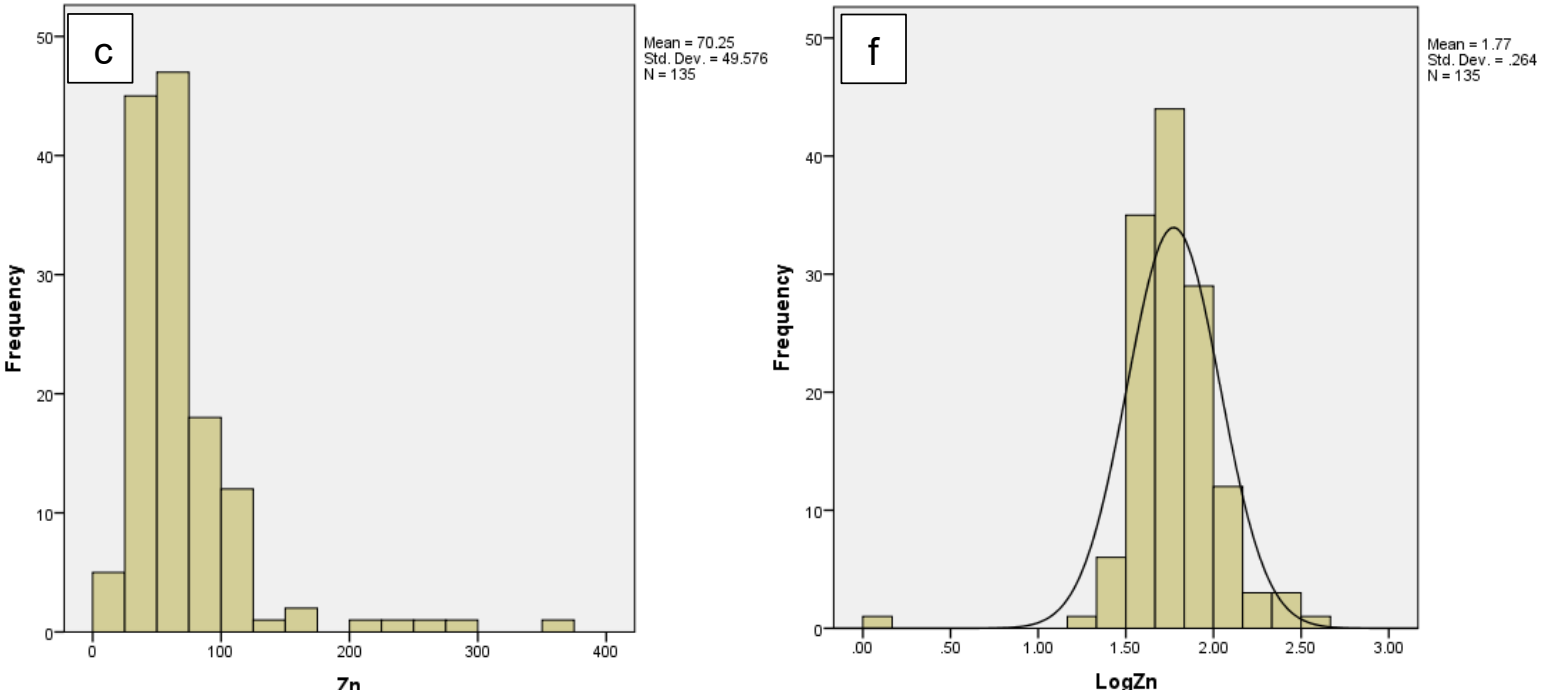

Gambar 6. Histogram dari a) unsur $\mathrm{Cu}, \mathrm{b}$ ) unsur $\mathrm{Pb}$ dan c) unsur $\mathrm{Zn}$ dari data asli geokimia; d) unsur $\mathrm{Cu}, \mathrm{e}$ ) unsur $\mathrm{Pb}$ dan f) unsur $\mathrm{Zn}$ dalam log-transformed 


\section{MAKALAH ILMIAH}
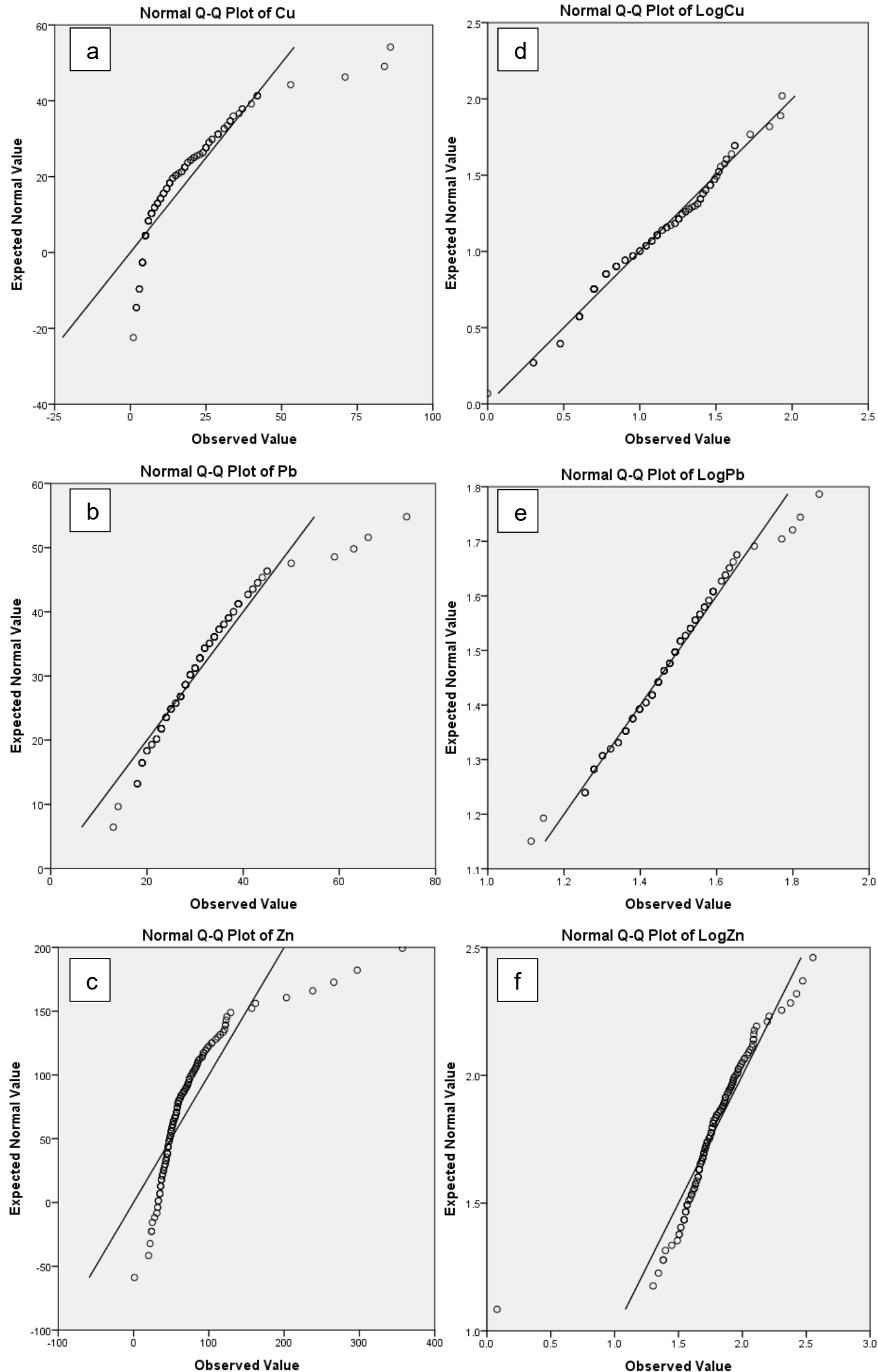

Gambar 7. Q-Q plot dari a) unsur $\mathrm{Cu}, \mathrm{b}$ ) unsur $\mathrm{Pb}$ dan c) unsur $\mathrm{Zn}$ dari data asli geokimia; d) unsur $\mathrm{Cu}, \mathrm{e}$ ) unsur $\mathrm{Pb}$ dan f) unsur $\mathrm{Zn}$ dalam log-transformed 


\section{MAKALAH ILMIAH}
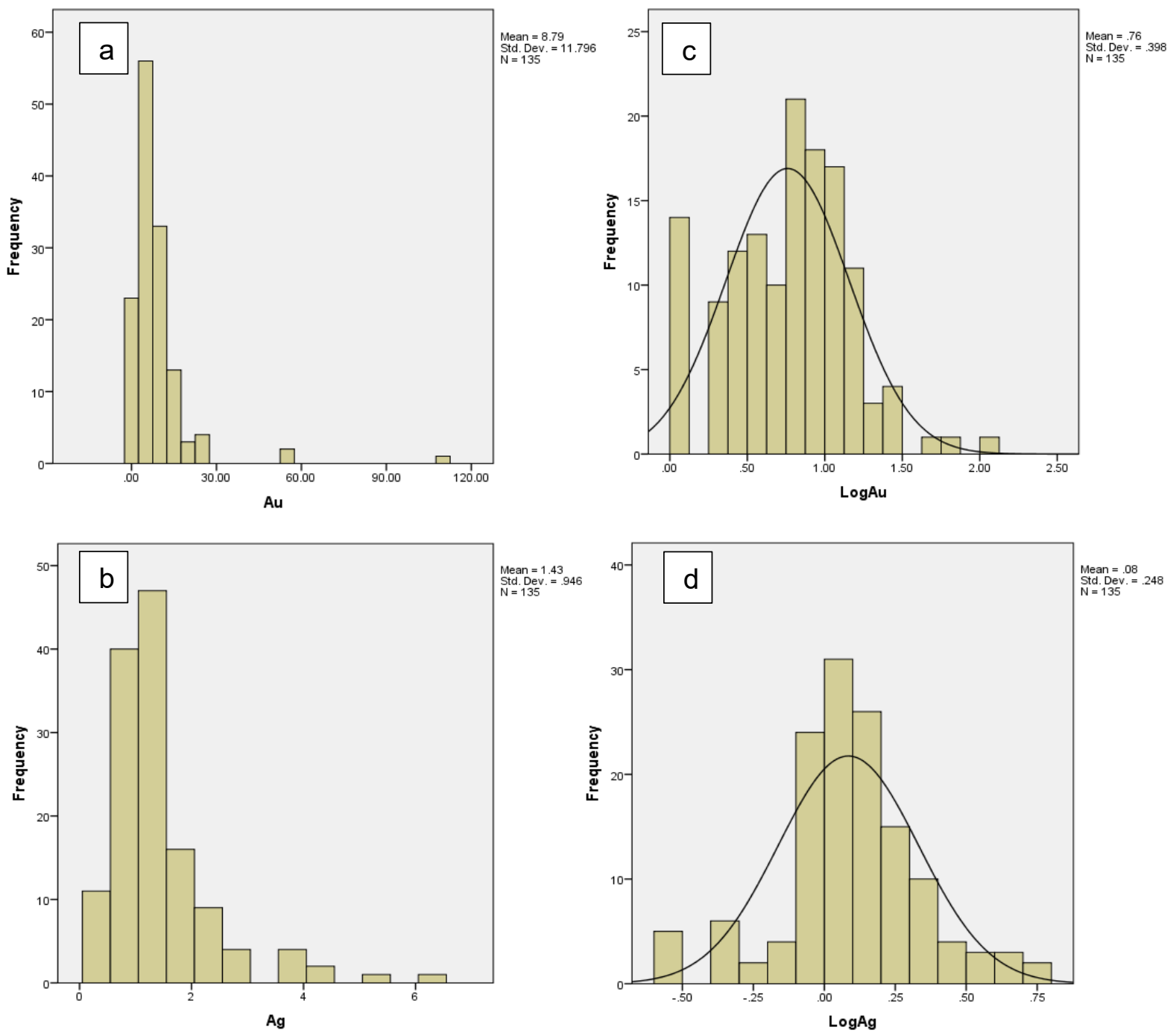

Gambar 8. Histogram dari a) unsur $\mathrm{Au}, \mathrm{b}$ ) unsur $\mathrm{Ag}$ dari data asli geokimia; c) unsur $\mathrm{Au \text {, }}$ d) unsur Ag dalam log-transformed

Penentuan anomali unsur ditentukan dari nilai threshold. Nilai threshold dihitung dengan rumus mean+2SDEV dan median+2MAD untuk masing-masing data asli maupun yang sudah ditransformasikan dari setiap unsur (Tabel 2). Untuk nilai threshold dari data asli dengan perhitungan mean+2SDEV dari keseluruhan unsur nilainya lebih tinggi dibandingkan nilai threshold dengan metode perhitungan median+2MAD, kecuali untuk unsur $\mathrm{Ag}$ yang relatif lebih rendah (Gambar 9). Nilai threshold unsur $\mathrm{Ag}$ dari data asli dengan perhitungan mean+2SDEV sebesar 2,199 ppm dan nilai maksimum sebesar 6,3 ppm sehingga metode perhitungan ini menghasilkan anomali. Sementara itu, perhitungan nilai threshold dengan perhitungan median+2MAD nilainya lebih besar dibandingkan nilai maksimum dari unsur $\mathrm{Ag}$, sehingga tidak menghasilkan suatu nilai anomali. Selain itu, nilai threshold dari log-tranformed data dari perhitungan dengan metode mean+2SDEV terhadap keseluruhan unsur lebih tinggi dibandingkan nilai threshold logtransformed data dari metode perhitungan median+2MAD (Gambar 10).

Dengan perhitungan nilai threshold tersebut dapat dilakukan delineasi daerah anomali. Seperti daerah anomali unsur $\mathrm{Cu}$ terdapat di daerah Bukit Pirang, Bukit Empaja dan Bukit Limau. Sedangkan daerah anomali unsur $\mathrm{Pb}$ terdapat di daerah Bukit Pirang dan Bukit Limau. 


\section{MAKALAH ILMIAH}

Tabel 2. Rekapitulasi nilai background dan threshold dari data geokimia tanah (background=mean, threshold=mean+2 sdev dan median+2 MAD)

\begin{tabular}{rlrrrrr}
\hline \multirow{2}{*}{ No Unsur } & \multirow{2}{*}{ Background } & \multicolumn{3}{c}{ Mean +2 SDEV } & \multicolumn{2}{c}{ Median +2 MAD } \\
\cline { 4 - 6 } & & & \multicolumn{1}{c}{ Asli } & anti-log 10 & Asli & anti-log 10 \\
\hline 1 & $\mathrm{Cu}$ & 15,867 & 35,324 & 62,195 & 25,000 & 53,240 \\
2 & $\mathrm{~Pb}$ & 30,622 & 43,059 & 51,617 & 39,000 & 39,862 \\
3 & $\mathrm{Zn}$ & 70,253 & 112,606 & 200,083 & 91,000 & 100,158 \\
4 & $\mathrm{Mn}$ & 155,126 & 247,884 & 444,048 & 207,000 & 276,982 \\
5 & $\mathrm{Fe}$ & 2,978 & 5,143 & 6,350 & 4,520 & 5,237 \\
6 & $\mathrm{Ag}$ & 1,434 & 2,199 & 3,802 & 7,200 & 2,133 \\
7 & $\mathrm{Au}$ & 9,61 & 16,113 & 35,104 & 12,000 & 16,667 \\
\hline
\end{tabular}
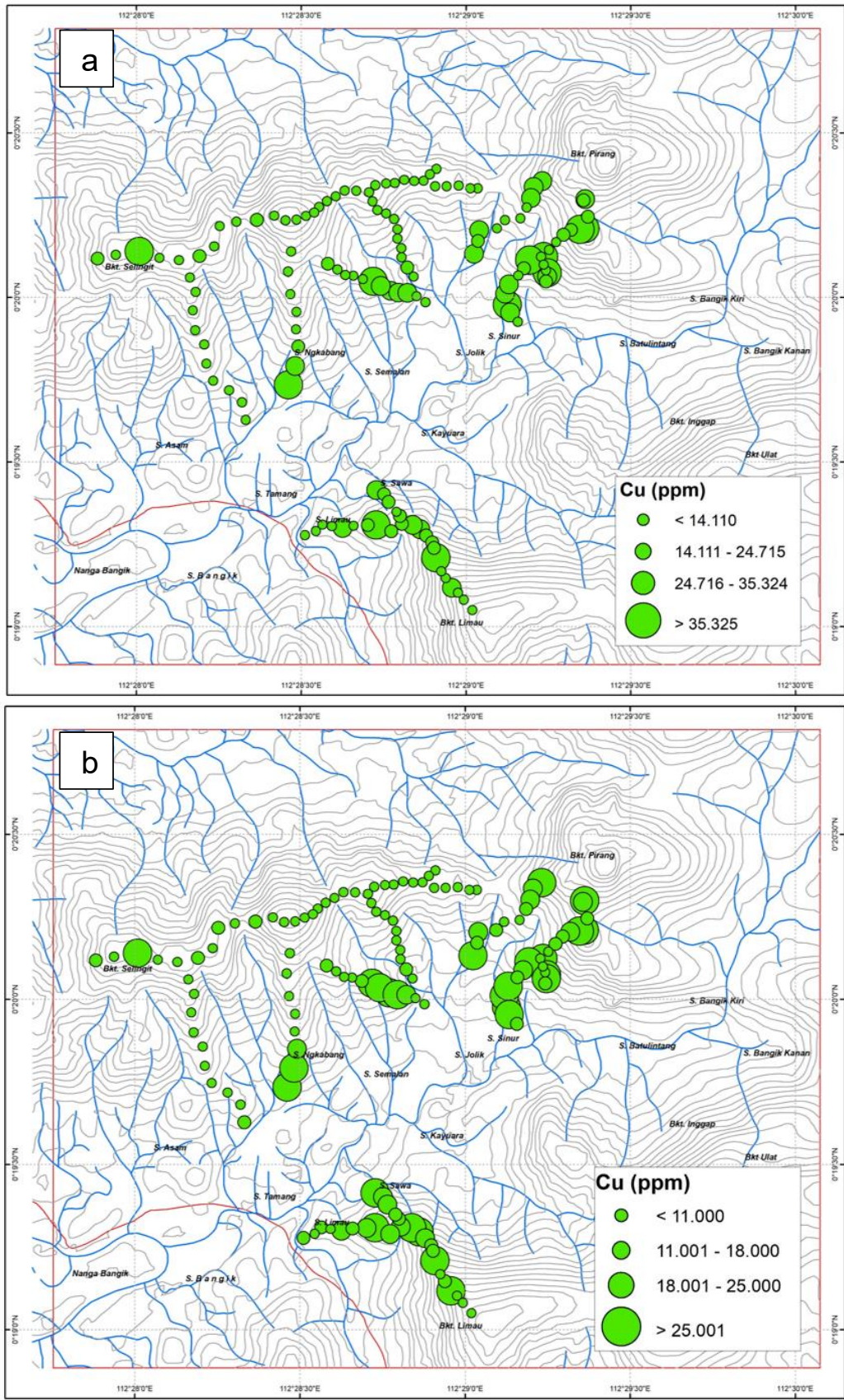

Gambar 9. Peta sebaran dan anomali unsur Cu dengan metode perhitungan nilai threshold a) mean+2SDEV dan b) median+2MAD pada data asli 


\section{MAKALAH ILMIAH}
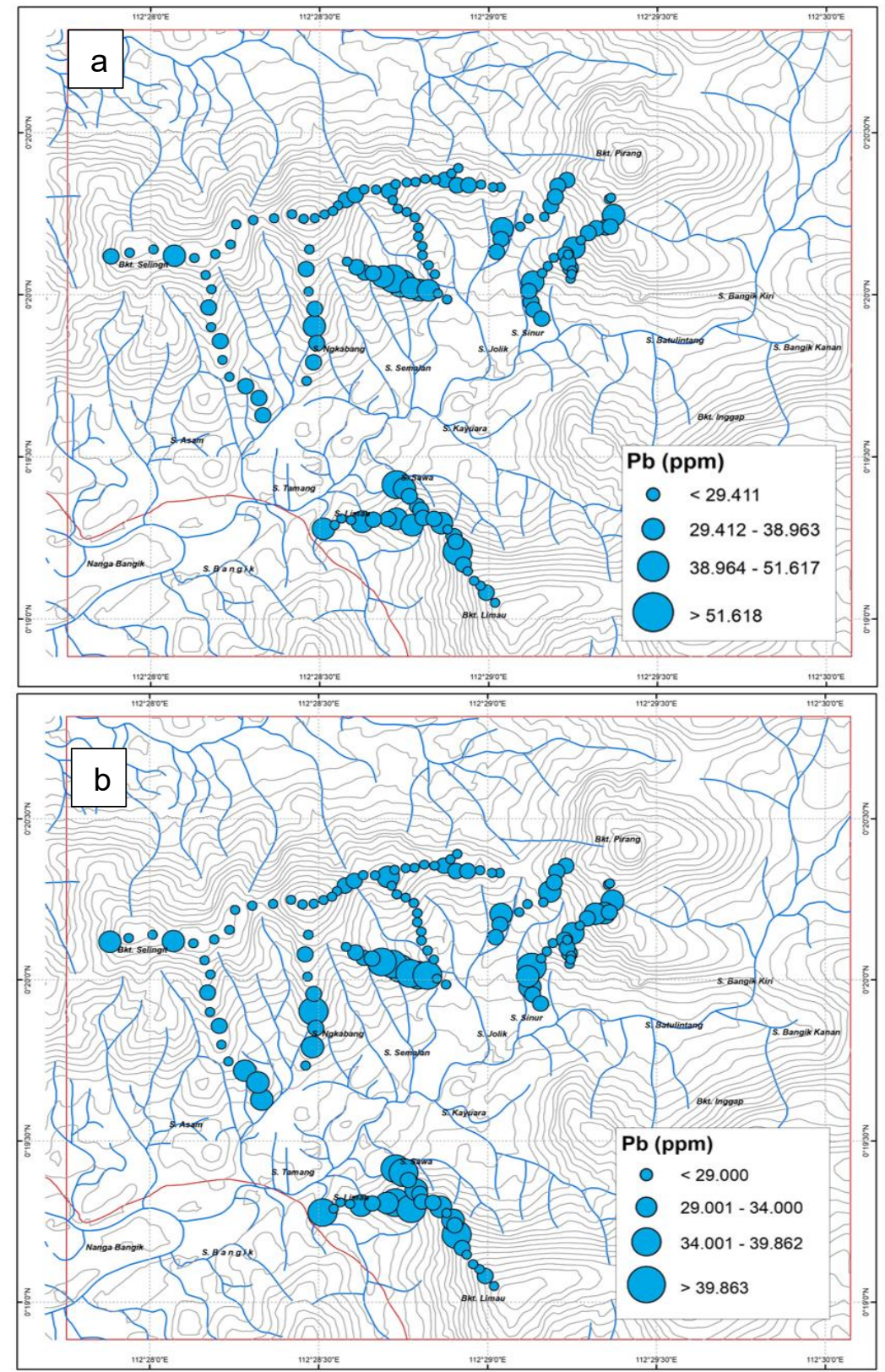

Gambar 10. Peta sebaran dan anomali unsur $\mathrm{Pb}$ dengan metode perhitungan nilai threshold a) mean+2SDEV dan b) median+2MAD pada log-transformed data

Scatterplot dapat berguna secara visual untuk mengetahui hubungan antar unsur. Scatterplot dari data dengan distribusi normal (simetri) atau yang mendekati normal akan optimal dalam analisis hubungan antar unsur secara visual (Carranza, 2008). Scatterplot pada Gambar 11 menunjukkan bahwa unsurunsur dari data geokimia tanah daerah penyelidikan mempunyai hubungan yang positif. Interpretasi visual dari scatterplot dapat ditambahkan dengan nilai dari koefisien korelasi dari dua unsur (Tabel 3).
Dari koefisien korelasi tersebut menunjukkan bahwa setiap unsur memiliki korelasi yang positif. Nilai koefisien korelasi yang paling kuat adalah koefisien korelasi antara unsur $\mathrm{Cu}$ dengan $\mathrm{Fe}$.

Analisis multivariat dilakukan untuk mengetahui korelasi antar unsur dan faktor analisis menggunakan metode Principal Component Analysis (PCA) dan varimax rotation (Tabel 4). Hasil analisis faktor menunjukkan adanya tiga kelompok asosiasi unsur. 


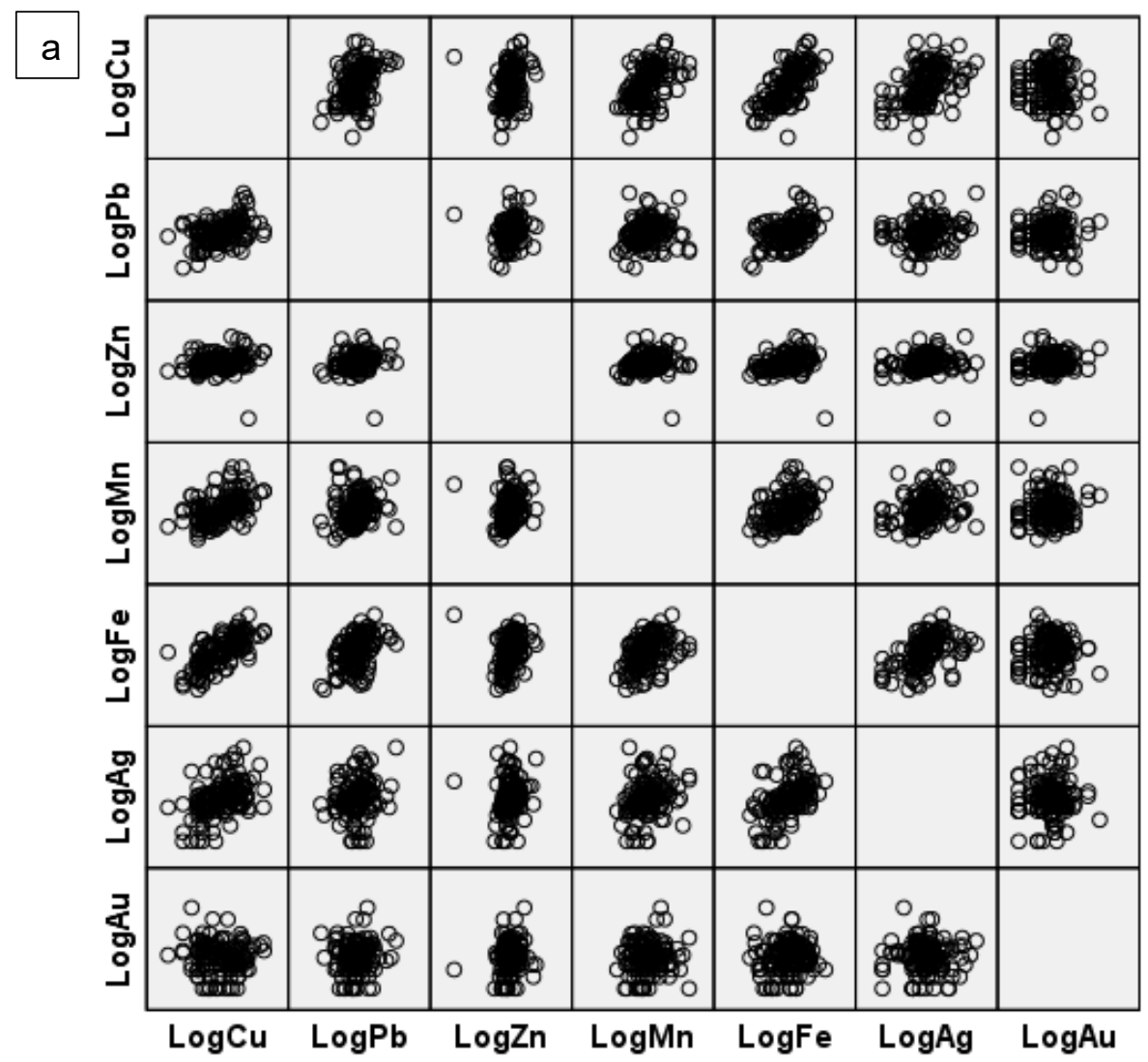

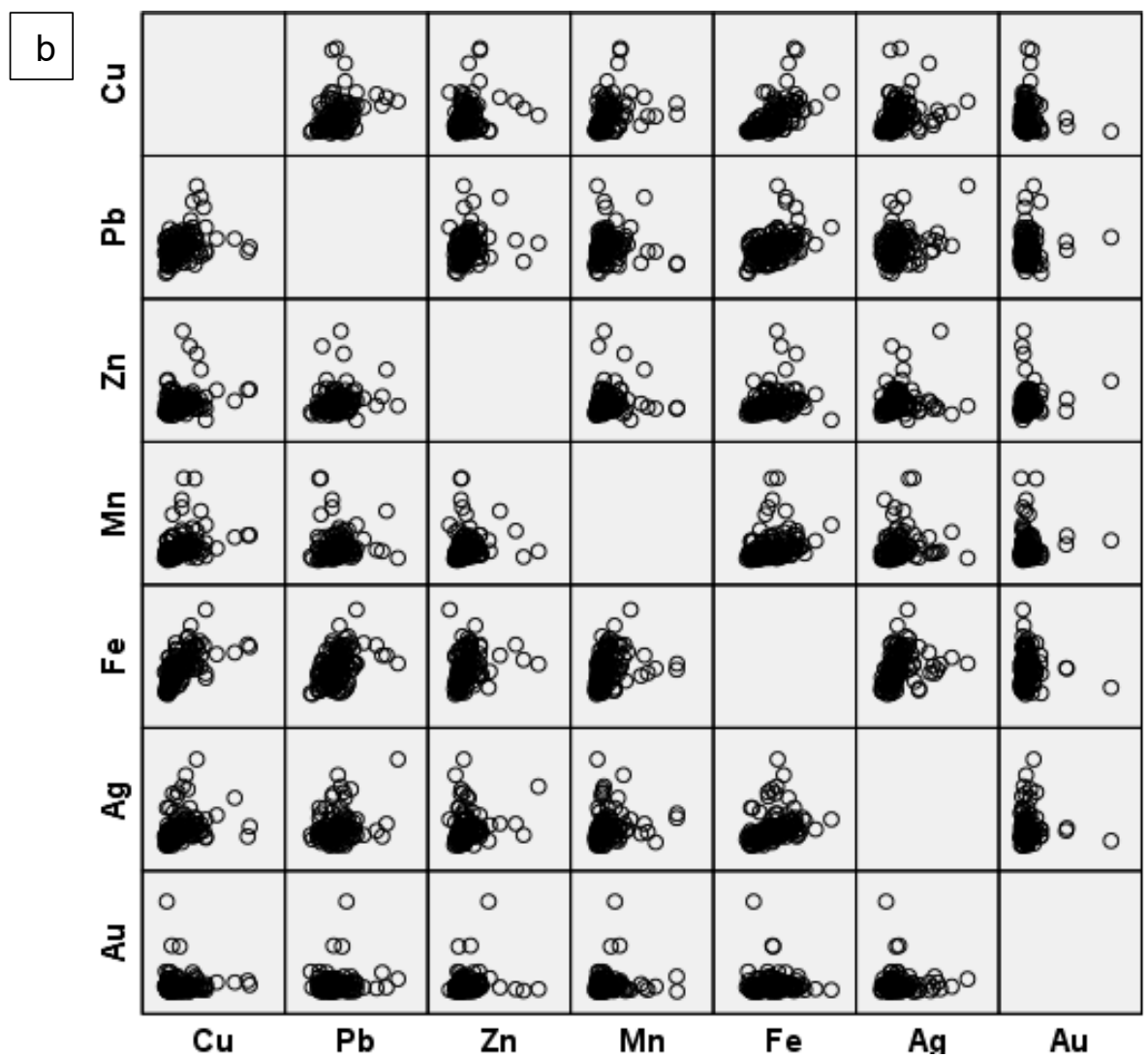

Gambar 11. Scatterplot dari data geokimia tanah daerah Nanga Bangik a) log-transformed data. b) data asli 


\section{MAKALAH ILMIAH}

Tabel 3. Korelasi koefisien dari log-transformed data geokimia tanah Daerah Nanga Bangik

\begin{tabular}{lrrrrrrr} 
& \multicolumn{1}{c}{ LogCu } & LogPb & LogZn & LogMn & LogFe & LogAg & LogAu \\
\hline LogCu & 1 & & & & & & \\
LogPb & 0,437423 & 1 & & & & & \\
LogZn & 0,198827 & 0,191565 & 1 & & & & \\
LogMn & 0,48802 & 0,178097 & 0,116687 & 1 & & & \\
LogFe & 0,713875 & 0,459044 & 0,20647 & 0,41457 & 1 & \\
LogAg & 0,438402 & 0,190026 & 0,142174 & 0,264737 & 0,486882 & & \\
LogAu & 0,016194 & 0,114648 & 0,141937 & 0,114246 & 0,094853 & 0,014549 & 1 \\
\hline
\end{tabular}

Tabel 4. Model ekstraksi: Principal Component Analysis (PCA) dan varimax rotation

\begin{tabular}{lcc}
\hline \multicolumn{1}{c}{ Unsur } & Faktor 1 & Faktor 2 \\
\hline $\mathrm{Pb}$ & 0,761 & 0,0723 \\
$\mathrm{Fe}$ & 0,619 & 0,540 \\
$\mathrm{Zn}$ & 0,593 & $-0,066$ \\
$\mathrm{Ag}$ & 0,543 & 0,214 \\
$\mathrm{Mn}$ & $-0,117$ & 0,886 \\
$\mathrm{Cu}$ & 0,521 & 0,648 \\
Eigen values & 2,442 & 1,002 \\
$\%$ of Variance & 40,707 & 16,706 \\
$\%$ cummulative & 40,707 & 57,414 \\
\hline
\end{tabular}

Faktor 1: Pb-Fe-Zn-Ag

Faktor 1 mempunyai nilai $40,707 \%$ dari total varian data. Faktor ini kemungkinan dikontrol oleh adanya mineralisasi sulfida. Unsur Fe umumnya berasosiasi dengan batuan mafik yang terepresentasikan di daerah penyelidikan pada pelapukan dari batuan tersebut. Unsur $\mathrm{Pb}$ mempunyai nilai loading 0,761 dari kadar unsur $\mathrm{Pb}$. Unsur Fe mempunyai nilai loading $0,619, \mathrm{Zn}$ $(0,593)$ dan $\mathrm{Ag}(0,543)$ dari kadar setiap unsurnya.

Dari hasil analisis laboratorium, hasil analisis mineragrafi teridentifikasi mineral sfalerit dan mineral sulfida lainnya yang tedapat di daerah Bukit Empajak-Pirang. Analisis mineralogi butir dari sampel pan concentrate di daerah Sungai Sawa Bukit Limau juga menunjukkan kehadiran perak (Gambar 12).

Faktor 2: $\mathrm{Mn}-\mathrm{Cu}$

Faktor 2 mempunyai nilai total varian data $16,706 \%$. Mn pada umumnya terbentuk sebagai oksida pada tanah lateritik dengan konsentrasinya lebih tinggi dari unsur lainnya. Faktor ini ada kemungkinan dikontrol oleh mineralisasi sulfida minor. $\mathrm{Mn}$ dan $\mathrm{Cu}$ masing-masing mempunyai nilai loading 0,886 dan 0,648.

Faktor 2 ini dicirikan dengan kehadiran mineral-mineral sulfida seperti kehadiran pirit, kalkopirit, sfalerit dan pirhotit. Mineralmineral tersebut teridentifikasi dari sampel batuan yang terdapat di daerah Bukit Pirang (Gambar 13).

Faktor $3: \mathrm{Au}$

Faktor 3 berupa unsur tunggal yaitu $A u$, hal ini dikarenakan nilai korelasi unsur $A u$ relatif kecil sehingga tidak memiliki korelasi dengan unsur lainnya. Diperkirakan pola dispersi Au berbeda dengan unsur lainnya. Kehadiran Au teridentifikasi dari konsentrat dulang yang diambil di daerah Sungai Jolik (Gambar 14). 

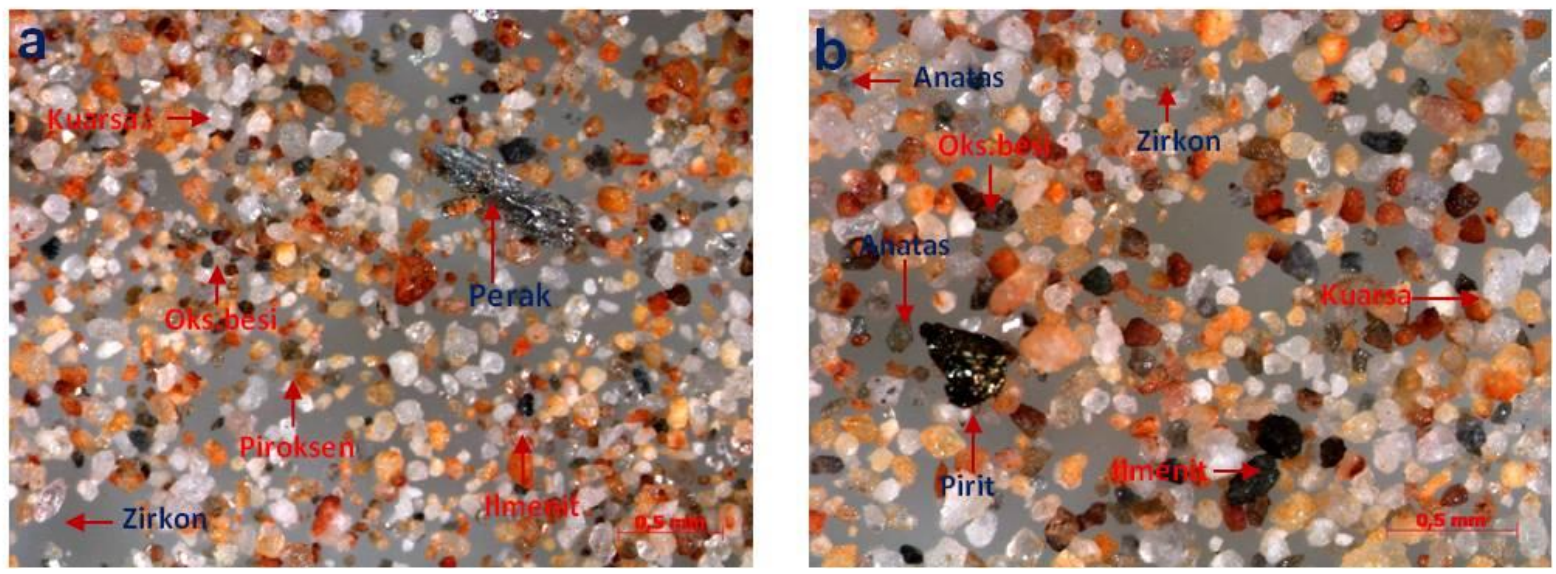

Gambar 12. Kehadiran perak pada sampel pan concentrate

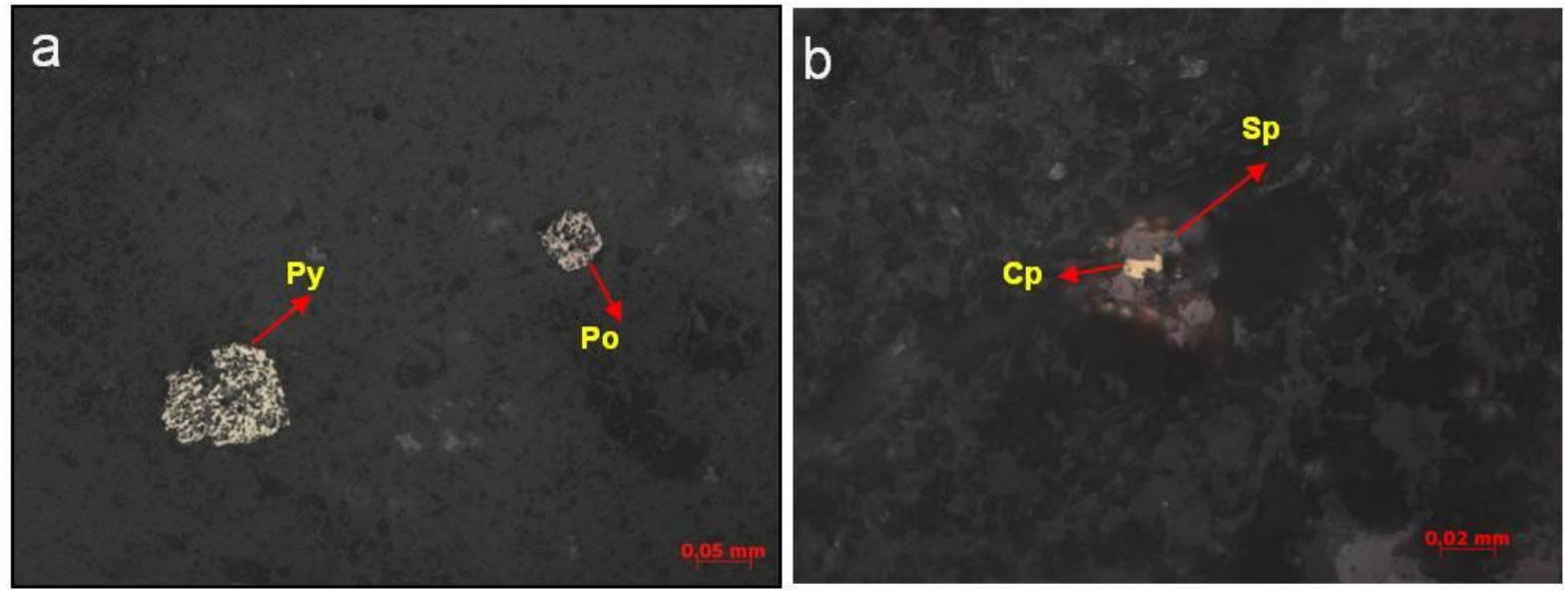

Gambar 13. Fotomikrograf: a) Pirhotit (Po) dan pirit (Py) pada massa batuan.

b) Pirhotit (Po) dan pirit (Py) pada massa batuan

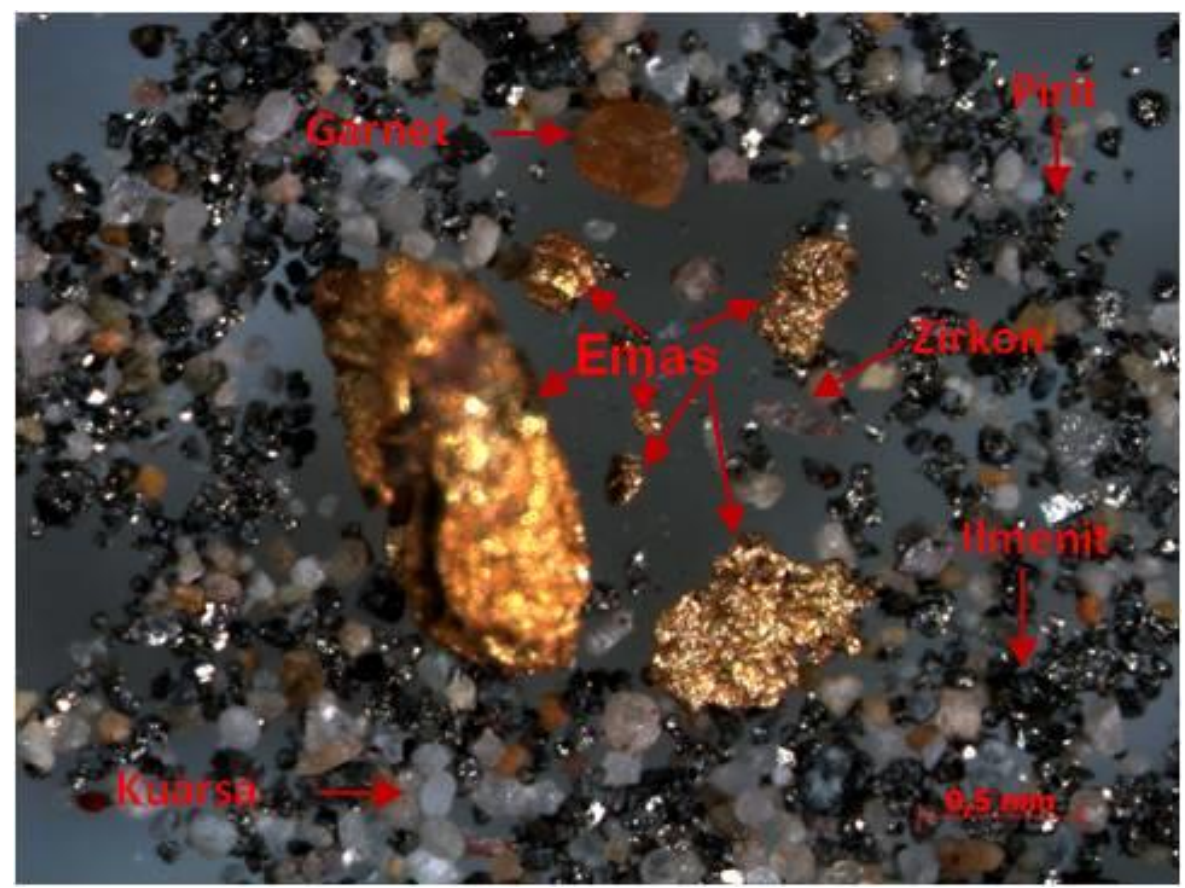

Gambar 14. Kehadiran Au (emas) pada sampel pan concentrate 


\section{MAKALAH ILMIAH}

Analisis korelasi antar unsur dengan metode faktor analisis, didapat 3 faktor, diantaranya faktor $1(\mathrm{~Pb}-\mathrm{Fe}-\mathrm{Zn}-\mathrm{Ag})$, faktor $2(\mathrm{Mn}-\mathrm{Cu})$ dan faktor $3(\mathrm{Au})$. Ketiga faktor ini ditafsirkan dikontrol oleh batuan, mineralisasi dan pelapukan serta pola dispersi. Adanya intrusi diorit menyebabkan terjadinya proses hidrotermal yang ditandai oleh zona ubahan argilik dan silisifikasi. Mineralisasi dicirikan dengan hadirnya mineral-mineral sulfida berupa pirit, kalkopirit dan sfalerit. Berdasarkan ketiga faktor analisis tersebut di atas dengan nilai-nilai loadings setiap unsur dapat menentukan daerah anomali. Penentuan daerah anomali dilakukan berdasarkan nilai threshold yang dihitung dari masing-masing faktor analisis (Tabel 5). Distribusi spasial dari ketiga faktor analisis tergambarkan pada peta sebaran dan anomali masing-masing faktor (Gambar 15, 16 dan 17).

Tabel 5. Nilai threshold dari masing-masing faktor

\begin{tabular}{|c|c|c|c|c|c|c|}
\hline \multirow{3}{*}{ No } & \multirow{3}{*}{ Komponen } & \multirow{3}{*}{ Background } & \multicolumn{4}{|c|}{ Threshold } \\
\hline & & & \multicolumn{2}{|c|}{ Mean + 2 SDEV } & \multicolumn{2}{|c|}{ Median + 2 MAD } \\
\hline & & & Asli & anti-log 10 & Asli & anti-log 10 \\
\hline 1 & $\begin{array}{l}\text { Faktor } 1(\mathrm{~Pb}- \\
\text { Fe-Zn-Ag) }\end{array}$ & 67,586 & 102.374 & 132.392 & 83.243 & 90.694 \\
\hline 2 & $\begin{array}{l}\text { Faktor } 2 \text { (Mn- } \\
\mathrm{Cu})\end{array}$ & 147,723 & 250.217 & 419.013 & 197.884 & 254.157 \\
\hline 3 & Faktor $3(\mathrm{Au})$ & 9,61 & 16,113 & 35,104 & 12,000 & 16,667 \\
\hline
\end{tabular}

(Faktor $1=0.761 \mathrm{~Pb}+0.619 \mathrm{Fe}+0.593 \mathrm{Zn}+0.543 \mathrm{Ag}$ dan Faktor2 $=0.886 \mathrm{Mn}+0.648 \mathrm{Cu})$
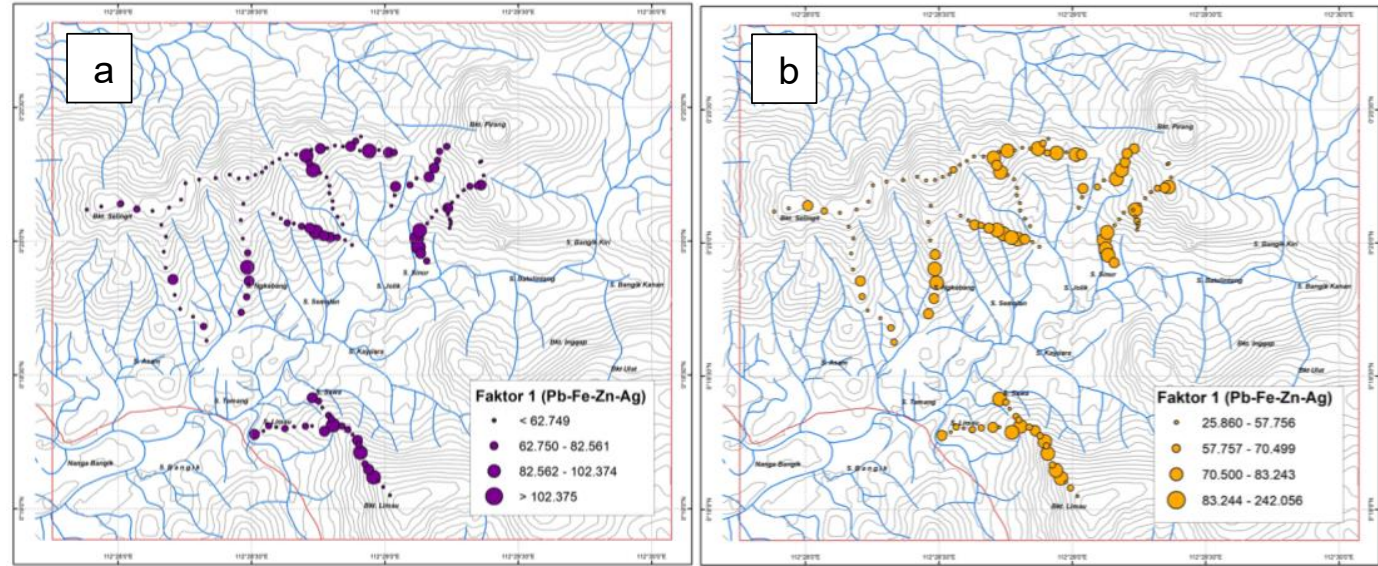

Gambar 15. Peta sebaran dan anomali Faktor 1 (Pb-Fe-Zn-Ag) dengan metode perhitungan nilai threshold a) mean+2SDEV dan b) median+2MAD pada data asli
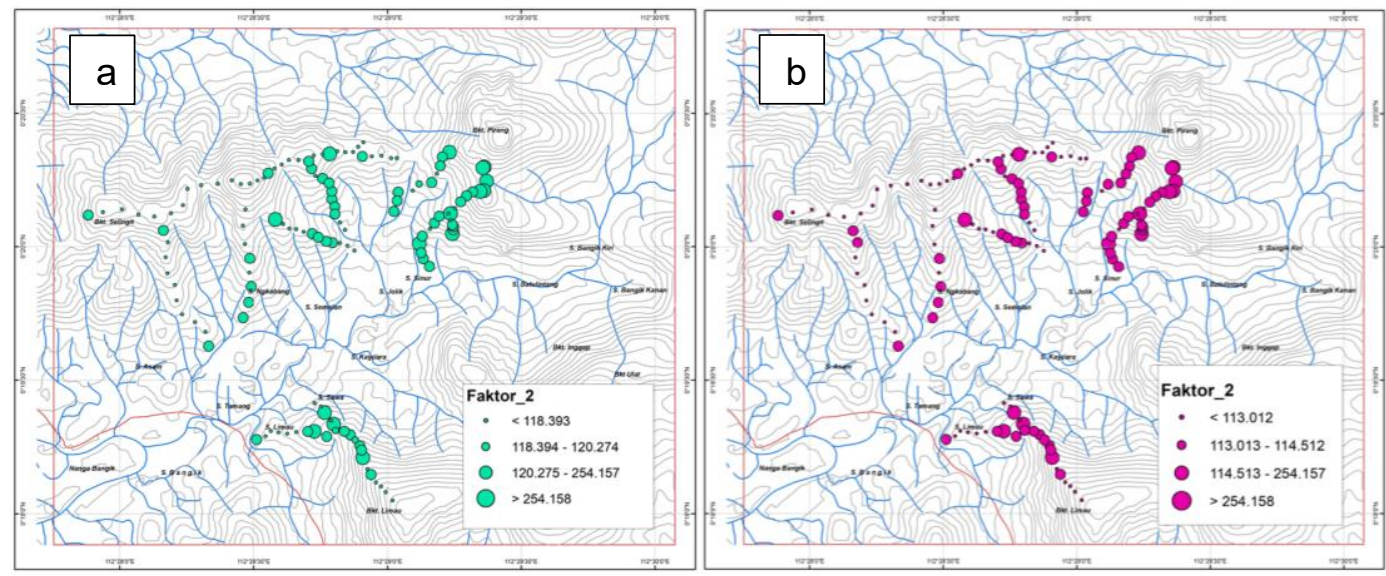

Gambar 16. Peta sebaran dan anomali Faktor $2(\mathrm{Mn}-\mathrm{Cu})$ dengan metode perhitungan nilai threshold a) mean+2SDEV dan b) median+2MAD pada log-transforfmed data 


\section{MAKALAH ILMIAH}

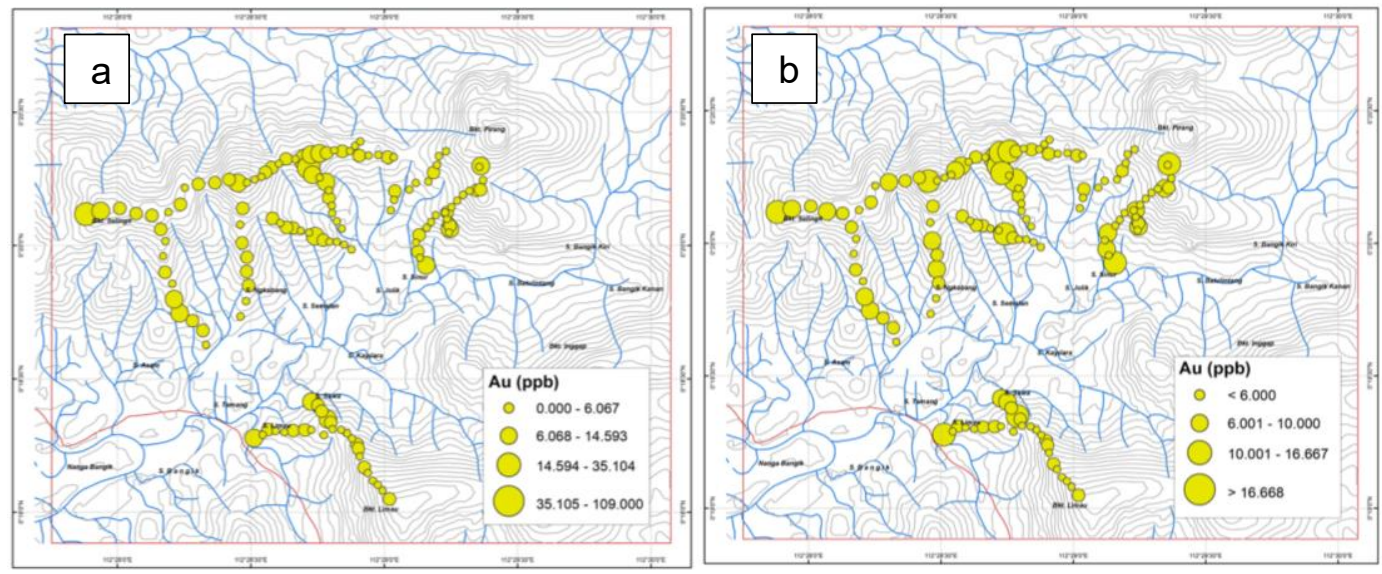

Gambar 17. Peta sebaran dan anomali Faktor $3(\mathrm{Au})$ dengan metode perhitungan nilai threshold a) mean+2SDEV dan b) median+2MAD pada log-transforfmed data

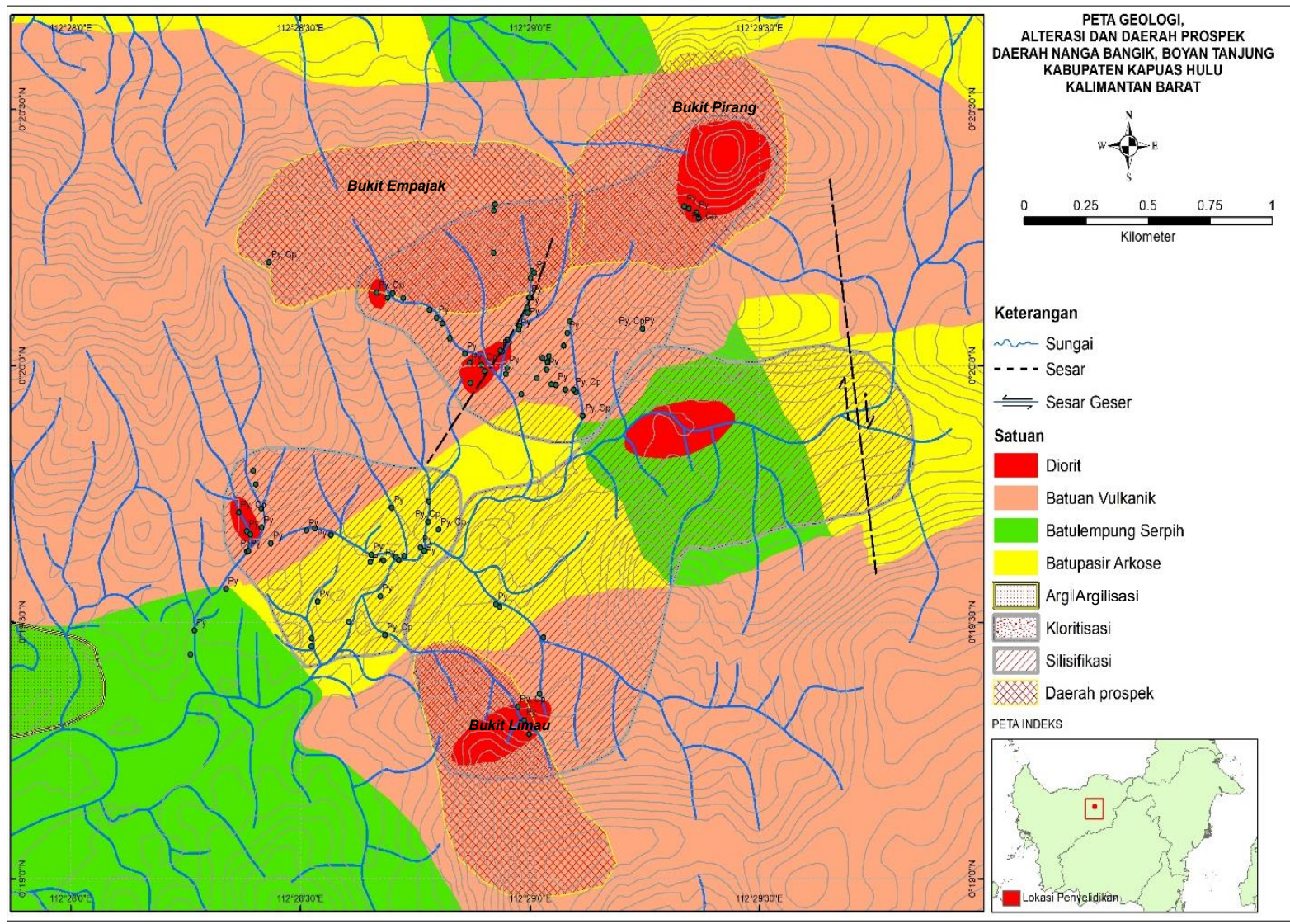

Gambar 18. Peta area prospek daerah penyelidikan

Berdasarkan kompilasi dari perhitungan threshold, korelasi univariat dan multivariat serta kenampakan di lapangan didapat tiga daerah prospek yang terdapat di Bukit Empajak, Bukit Pirang dan Bukit Limau (Gambar 18). Bukit Empajak dan Bukit Limau lebih di dominasi oleh asosiasi unsur $\mathrm{Pb}-\mathrm{Fe}-\mathrm{Zn}-\mathrm{Ag}$. Bukit Pirang didominasi oleh asosiasi unsur $\mathrm{Mn}-\mathrm{Cu}$. Sedangkan untuk unsur Au yang memiliki nilai kadar maksimum berada pada Bukit Empajak atau ujung Sungai Jolik pada cabang kiri.

\section{KESIMPULAN}

Korelasi antar unsur di daerah Nanga Bangik terbagi menjadi tiga asosiasi unsur yaitu $\mathrm{Pb}-\mathrm{Fe}-\mathrm{Zn}-\mathrm{Ag}$, $\mathrm{Mn}-\mathrm{Cu}$, dan $\mathrm{Au}$. 
Berdasarkan perhitungan nilai threshold yang dilakukan dengan dua metode statistik yang berbeda, didapatkan daerah anomali yang juga merupakan daerah prospek mineralisasi logam di Bukit Empajak, Bukit Pirang dan Bukit Limau. Indikasi mineralisasi di Bukit Empajak dan Bukit Limau lebih didominasi oleh asosiasi unsur $\mathrm{Pb}-\mathrm{Fe}-\mathrm{Zn}-\mathrm{Ag}$. Keterdapatan nilai kadar maksimum Au dan kehadiran emas pada konsentrat dulang dari Sungai Jolik mengkonfirmasi prospek emas berada pada Bukit Empajak. Sementara itu di Bukit Pirang didominasi oleh asosiasi unsur Mn$\mathrm{Cu}$.

\section{DAFTAR PUSTAKA}

Bradshaw, P.M.D., Lett, R.E.W. 1980. Geochemical exploration for uranium using soils.J. Geochem. Explor. 13, 305-319.

Carranza, E.J.M. 2008. Geochemical Anomaly and Mineral Prospectivity Mapping in GIS. Handbook of Exploration and Environmental Geochemistry, vol. 11. Elsevier, Amsterdam.

Carroll, J.B. 1953. An analytic solution for approximating simple structure in factor analysis. Psychometrika 18, 23-38.

Closs LG, Nichol I. 1975. The role of factor and regression analysis in the interpretation of geochemical reconnaissance data. Can $\mathrm{J}$ of Ear Sci 12: 1316-1330.

Garrett RG, Kane VE, Zeigler K. 1980. The management and analysis of regional geochemical data. J Geochem Explore 13:115-152.

Grunsky, E.C. 2010. The interpretation of geochemical survey data. Geochem. Explor. Environ.Anal. 10, 27-74.

Harman, H.H. 1976. Modern Factor Analysis, 3rd edition. University of Chicago Press, Chicago.

Hawkes, H.E., Webb, J.S. 1962. Geochemistry in Mineral Exploration. New York 7 Harper.
Hendrickson, A.E., White, P.O. 1964. PROMAX: a quick method for rotation to oblique simple structure. Br. J. Stat. Psychol. 17, 65-70.

Joseph, I., Bhaumik, B.K. 1997. Improved estimation of the Box-Cox transform parameter and its application to hydrogeochemical data. Mathematical Geology 29(8): 963976.

Kaiser, H.F. 1958. The Varimax criterion for analytic rotation in factor analysis. Psychometrika 23, 187-200.

Kisman, Bambang Pardiarto. 2015. Eksplorasi Umum Emas dan Mineral Ikutannya di Kecamatan Boyan Tanjung Kabupaten Kapuas Hulu Provinsi Kalimantan Barat. Pusat Sumber Daya Geologi. Bandung.

Kisman, Ernowo, Sulaeman. 2018. Prospeksi Lanjut Mineral Logam Di Daerah Nanga Bangik dan Sekitarnya Kecamatan Boyan Tanjung Kabupaten Kapuas Hulu Provinsi Kalimantan Barat. Pusat Sumber Daya Mineral Batubara dan Panas Bumi. Bandung.

Laurent M, Robin OP, Jean-Pierre T. 2010. Multivariate statistikal analysis of trace elements in soil on Spoil Heap, South East Congo-Brazzaville. African Journal of Basic and Applied Sciences 2: 81-88.

Miesch, A.T. 1977. Log-transformation in geochemistry. Mathematical Geology 9(2): 191-194.

Pieters, P.E., Surono dan Y. Noya, T.O. 1993. Peta Geologi Lembar Putissibau, Kalimantan, skala 1 : 250.000. Pusat Penelitian dan Pengembangan Geologi. Bandung.

Reimann, C., Filzmoser, P. 1999. Normal and lognormal data distribution in geochemistry: death of a myth. Consequences for the statistikal treatment of geochemical and environmental data. Environmental Geology 39(9): 1001-1014.

Reimann, C., Filzmoserb, P., Garrett, R.G. 2002. Factor analysis applied to regional geochemical data: problems and possibilities. Appl. Geochem. 17, 185-206. 


\section{MAKALAH ILMIAH}

Reimann, C., Filzmoserb, P., Garrett, R.G. 2005. Background and threshold: critical comparison of methods of determination. Sci. Total Environ. 346, 1-16.

Rose, A. W., Hawkes. H. E., Webb. J. S. 1979. Geochemistry in Mineral Exploration. 2nd edn. London: Academic Press.
Vistelius, A.B. 1960. The skew frequency distributions and the fundamental law of the geochemical processes. Journal of Geology 68(1):1-22.

\begin{tabular}{|ll|}
\hline Diterima & $:$. 7 Oktober 2021 \\
Direvisi & $: 28$ Oktober 2021 \\
Disetujui & $: 30$ November 2021 \\
\hline
\end{tabular}

